
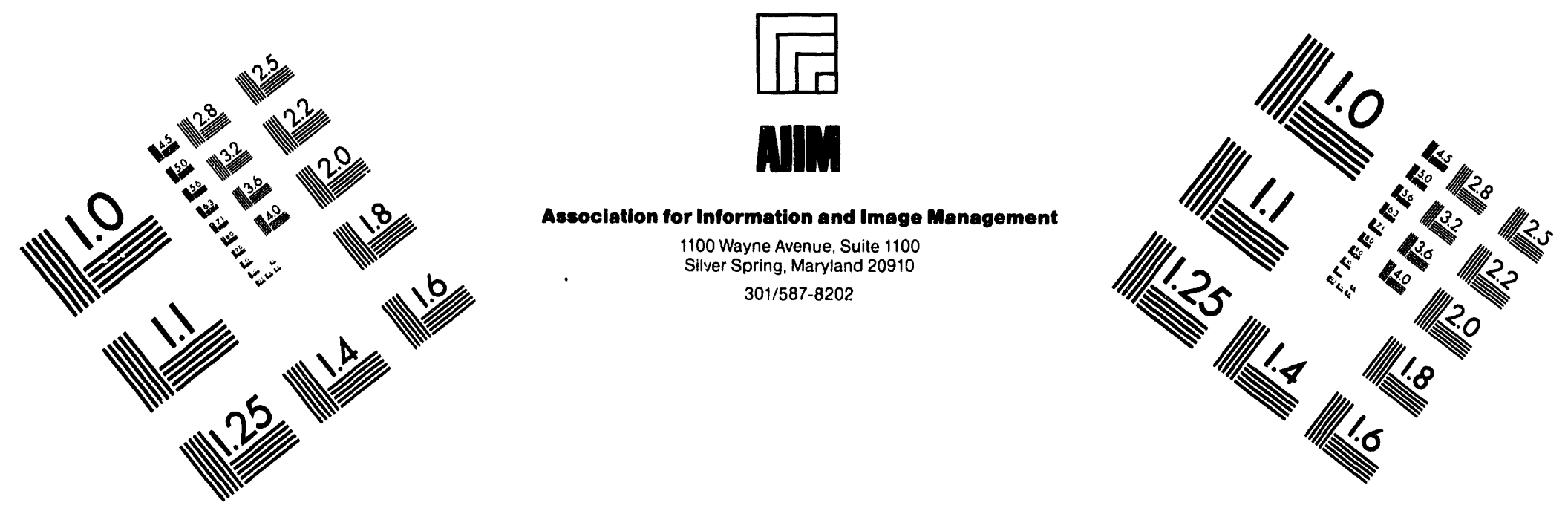

Centimeter

$\begin{array}{llllllllllllllll}1 & 2 & 3 & 4 & 5 & 6 & 7 & 8 & 9 & 10 & 11 & 12 & 13 & 14 & 15 & \mathrm{~mm}\end{array}$

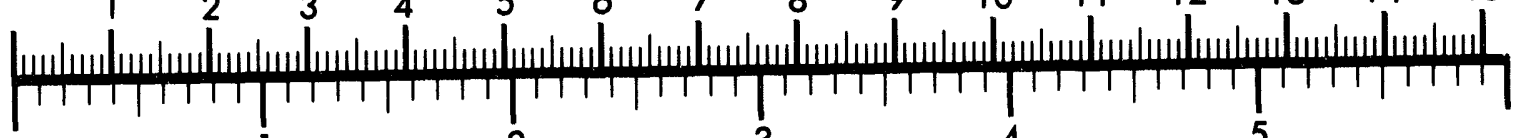
Inches

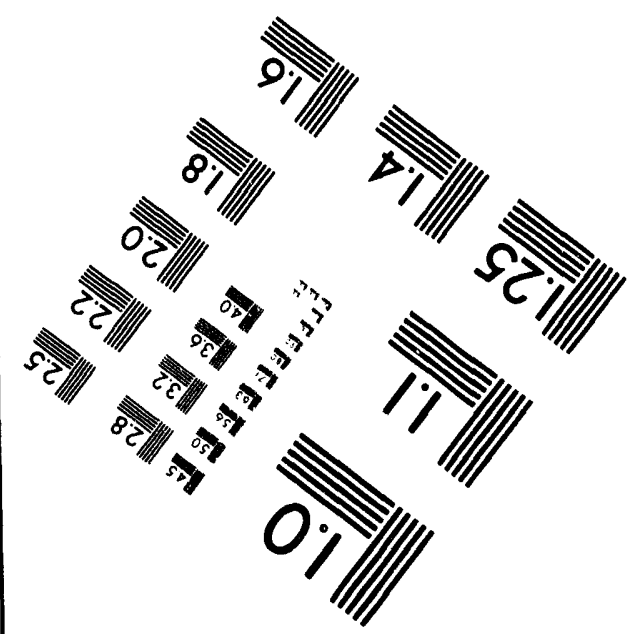

MANUFACTURED TO AIIM STANDARDS BY APPLIED IMAGE, INC.

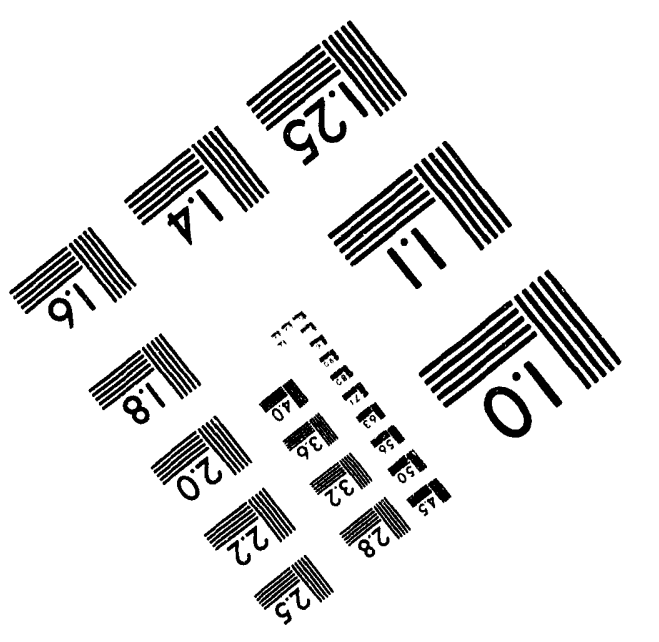



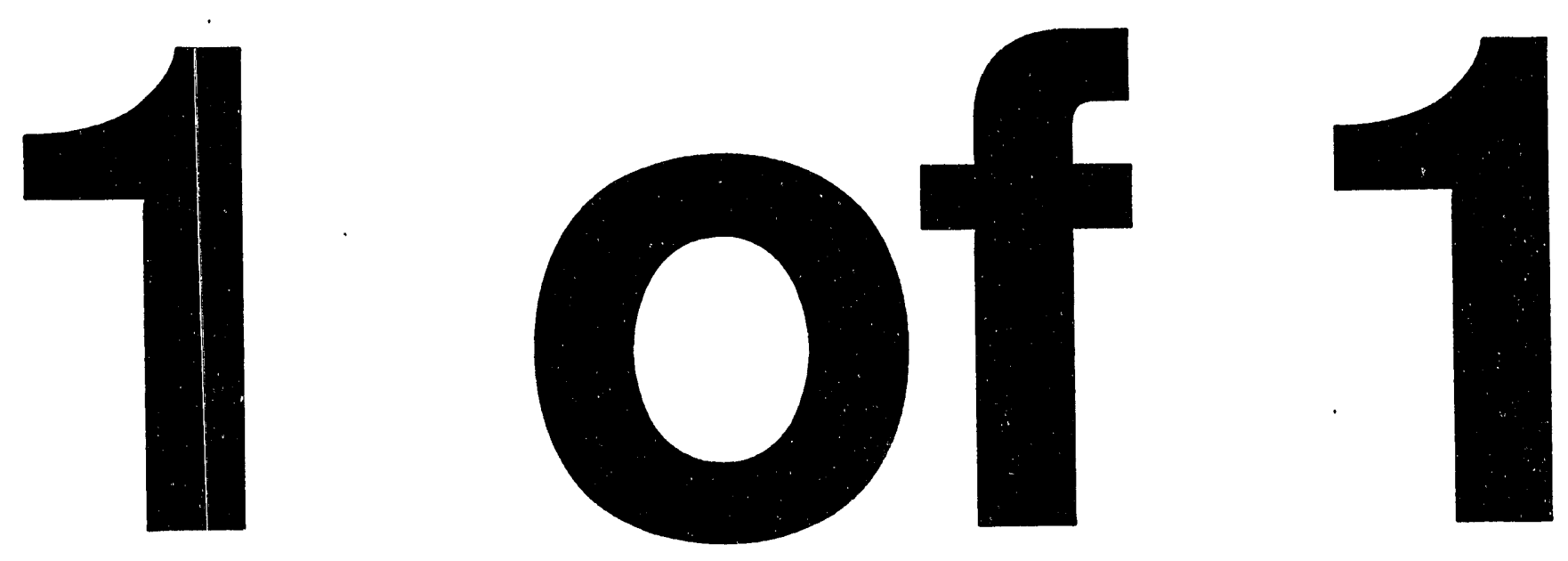
DOE/OR/01-1226/V1

Oak Ridge Reservation Federal Facility Agreement Quarterly Report

for the Environmental Restoration Program

\title{
Volume 1. October-Dicember 1993
}

\author{
Environmental Restoration Program \\ P.O. Box 2003 \\ Oak Ridge, Tennessee 37831-7298
}

Date Issued-January 1994

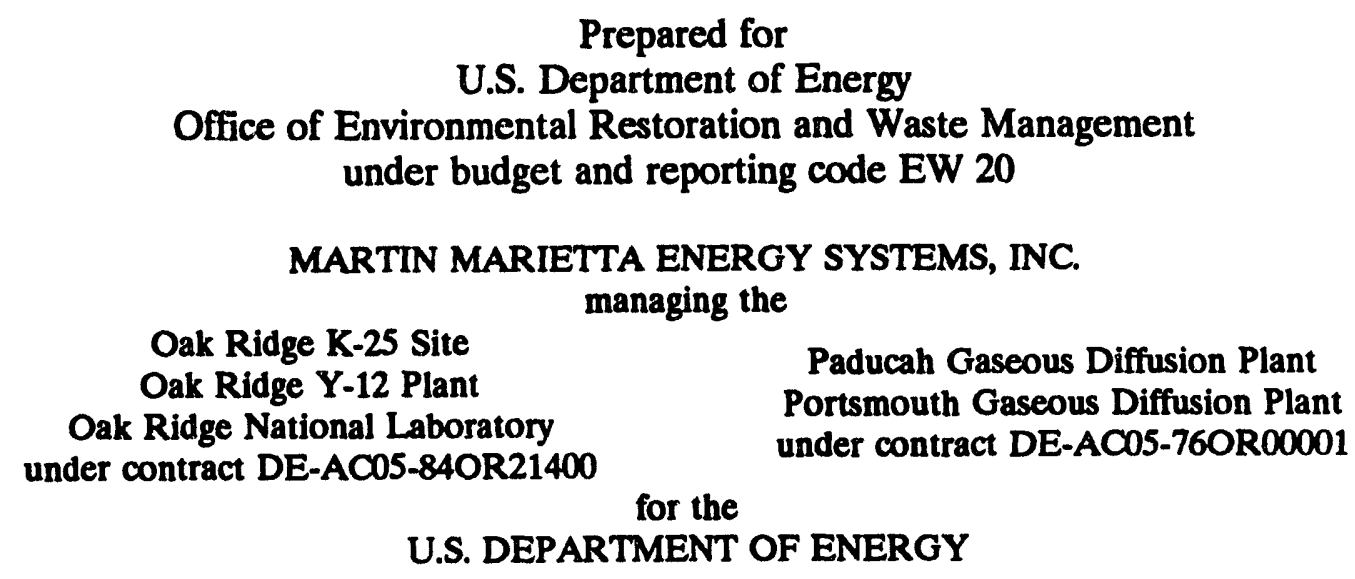




\section{CONTENTS}

ACRONYMS $\ldots \ldots \ldots \ldots \ldots \ldots \ldots \ldots \ldots \ldots \ldots \ldots \ldots \ldots \ldots \ldots \ldots \ldots$

1. EXECUTIVE SUMMARY $\ldots \ldots \ldots \ldots \ldots \ldots \ldots \ldots \ldots \ldots \ldots \ldots \ldots$

1.1 DOCUMENTS TRANSMITTED TO THE REGULATORS . . . . . . . . 1

1.2 DOCUMENTS PROPOSED FOR TRANSMITTAL ............. 1

2. SIGNIFICANT ACCOMPLISHMENTS $\ldots \ldots \ldots \ldots \ldots \ldots \ldots \ldots \ldots \ldots$

3. TECHNICAL STATUS $\ldots \ldots \ldots \ldots \ldots \ldots \ldots \ldots \ldots \ldots \ldots \ldots \ldots \ldots \ldots \ldots$

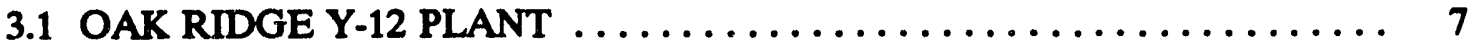

3.1.1 Upper EFPC OU 1 (Groundwater) ................. 8

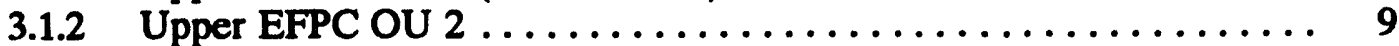

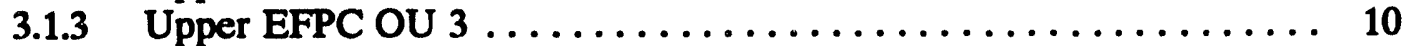

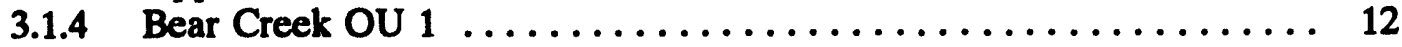

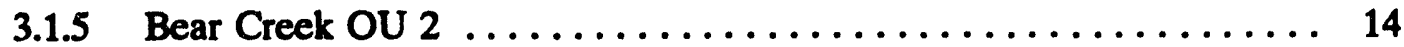

3.1.6 Bear Creek OU 4 (Groundwater) .................... 15

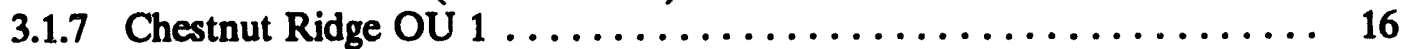

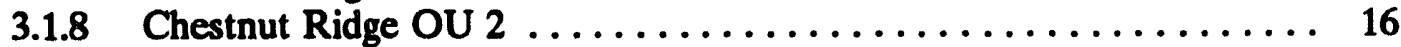

3.1 .9 Chestnut Ridge OU $4 \ldots \ldots \ldots \ldots \ldots \ldots \ldots \ldots \ldots \ldots \ldots \ldots \ldots$

3.1 .10 Lower EFPC . . . . . . . . . . . . . . . . . . . . . 18

3.1.11 Reduction of Mercury in Plant Effluents (RMPE) ............ 19

3.1.12 RCRA Closures .......................... 20

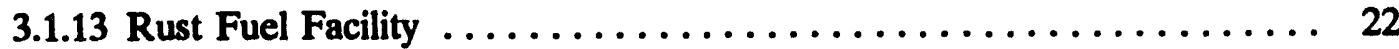

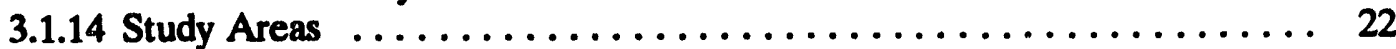

3.2 OAK RIDGE NATIONAL LABORATORY $\ldots \ldots \ldots \ldots \ldots \ldots \ldots \ldots$

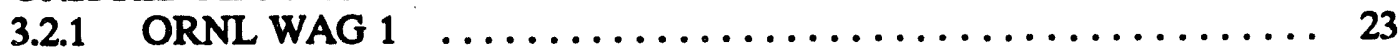

3.2.2 Inactive Liquid Low-Level Radioactive Waste Tanks . . . . . . . . . 24

3.2.3 Active Liquid Low-Level Radioactive Waste Tanks ............ 25

3.2.4 ORNL WAG 2 (White Oak Creek Embayment/Tributaries/Soil OU 1) 25

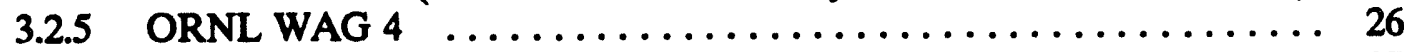

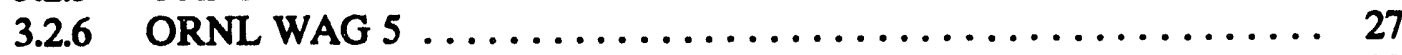

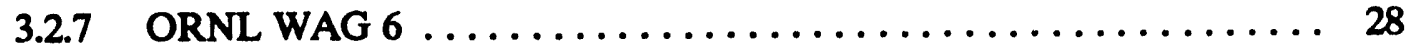

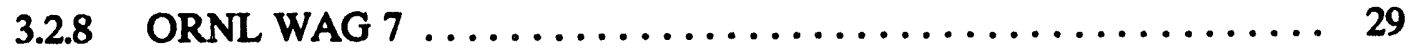

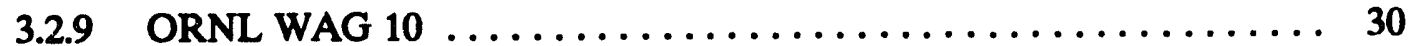

3.2 .10 ORNL WAG $11 \ldots \ldots \ldots \ldots \ldots \ldots \ldots \ldots \ldots \ldots \ldots \ldots \ldots \ldots \ldots$

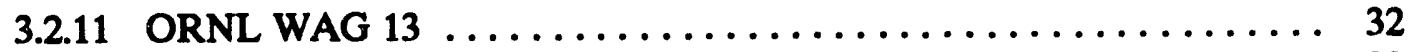

3.2.12 ORNL Groundwater OU/Well Plugging and Abandonment . . . . . 33

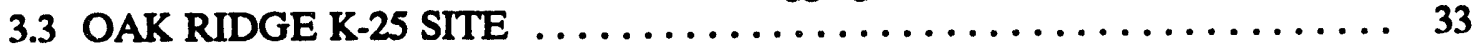

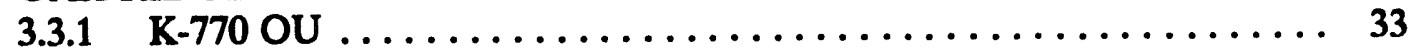

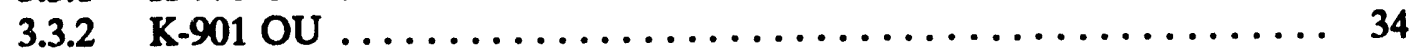

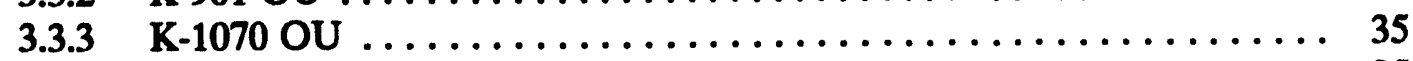

3.3.4 K-1070 SW-31 Spring Project $\ldots \ldots \ldots \ldots \ldots \ldots \ldots \ldots \ldots \ldots \ldots \ldots \ldots$ 


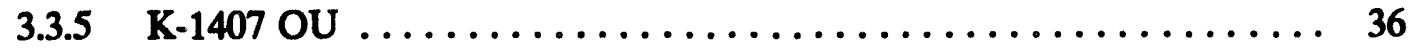

3.3.6 Pond Waste Management Project $\ldots \ldots \ldots \ldots \ldots \ldots \ldots \ldots \ldots . \quad 37$

3.3.7 K-1414 Bioremediation (Underground Storage Tank Early Action) . . . 38

3.4 CLINCH RIVER $\ldots \ldots \ldots \ldots \ldots \ldots \ldots \ldots \ldots \ldots \ldots \ldots \ldots \ldots \ldots, \ldots \ldots \ldots$

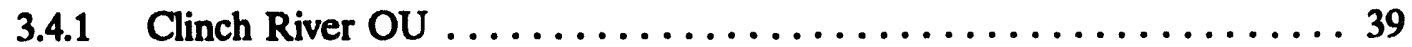

3.4.2 Lower Watts Bar Reservoir OU ..................... 41

3.5 OAK RIDGE ASSOCIATED UNIVERSITIES (ORAU) $\ldots \ldots \ldots \ldots \ldots \ldots, 42$

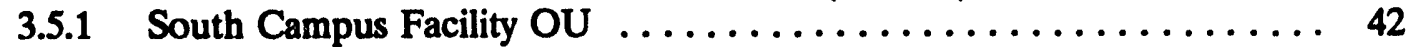

3.5.2 Freels Bend Area OU $\ldots \ldots \ldots \ldots \ldots \ldots \ldots \ldots \ldots \ldots \ldots, 43$

3.6 TECHNICAL OVERSIGHT AND TECHNICAL PROGRAMS $\ldots \ldots \ldots \ldots 44$

3.6.1 Background Soil Characterization Project $\ldots \ldots \ldots \ldots \ldots \ldots \ldots, 44$

3.6.2 Oak Ridge Environmental Information System $\ldots \ldots \ldots \ldots \ldots \ldots .44$

3.6.3 Aerial Remote Sensing Surveys $\ldots \ldots \ldots \ldots \ldots \ldots \ldots \ldots \ldots \ldots, 46$

3.6.4 Risk Assessment Program ...................... 48

3.6.5 Federal Facility Agreement and Tennessee Oversight Agreement .... 50

4. RESPONSE ACTION CONTRACTOR ASSIGNMENTS $\ldots \ldots \ldots \ldots \ldots \ldots, 52$

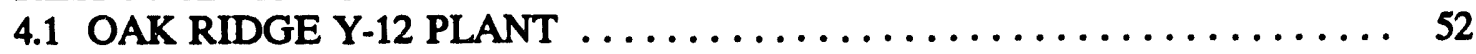

4.2 OAK RIDGE NATIONAL LABORATORY $\ldots \ldots \ldots \ldots \ldots \ldots \ldots \ldots, 53$

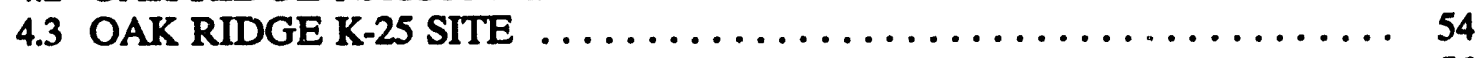

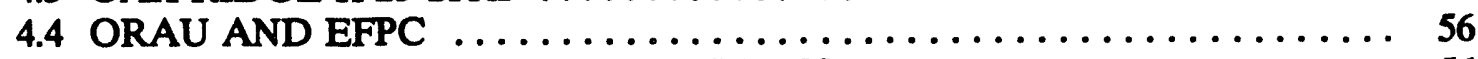

4.5 CLINCH RIVER-WATTS BAR RESERVOIR $\ldots \ldots \ldots \ldots \ldots \ldots \ldots \ldots, 56$

4.6 ENERGY SYSTEMS ER CENTRAL DIVISION $\ldots \ldots \ldots \ldots \ldots \ldots \ldots, 58$

4.7 JACOBS ENGINEERING $\ldots \ldots \ldots \ldots \ldots \ldots \ldots \ldots \ldots \ldots \ldots \ldots$ 


\section{ACRONYMS}

\begin{tabular}{|c|c|}
\hline $\begin{array}{l}\text { APO } \\
\text { BSCP }\end{array}$ & $\begin{array}{l}\text { Analytical Projects Office } \\
\text { Background Soil Characterization Project }\end{array}$ \\
\hline CERCLA & Comprehensive Environmental Response, Compensation, and Liability Act \\
\hline D\&D & decontamination and decommissioning \\
\hline DNAPLs & dense, nonaqueous-phase liquids \\
\hline DOE & Department of Energy \\
\hline DOE-HQ & DOE Headquarters \\
\hline DOE-ORO & DOE Oak Ridge Operations Office \\
\hline DQO & data quality objective \\
\hline EFPC & East Fork Poplar Creek \\
\hline EIS & Environmental Impact Statement \\
\hline EPA & Environmental Protection Agency \\
\hline ER & Environmental Restoration \\
\hline FFA & Federal Facility Agreement \\
\hline FS & feasibility study \\
\hline GWPP & Groundwater Protection Program \\
\hline LDRIF & Low Dose Rate Irradiation Facility \\
\hline LLLW & liquid low-level radioactive waste \\
\hline NEPA & National Environmental Policy Act \\
\hline NFA & no further action \\
\hline NPDES & National Pollutant Discharge Elimination System \\
\hline OHF & Old Hydrofracture Facility \\
\hline ORAU & Oak Ridge Associated Universities \\
\hline OREIS & Oak Ridge Environmental Information System \\
\hline ORNL & Oak Ridge National Laboratory \\
\hline ORR & Oak Ridge Reservation \\
\hline OU & operable unit \\
\hline PASSI & Preliminary Assessment/Site Inspection \\
\hline PCB & polychlorinated biphenyl \\
\hline RCRA & Resource Conservation and Recovery Act \\
\hline $\mathbf{R I}$ & remedial investigation \\
\hline RMPE & reduction of mercury in plant effluents \\
\hline ROD & Record of Decision \\
\hline SAIC & Science Applications International Corporation \\
\hline SCF & South Campus Facility (ORAU) \\
\hline SSAB & Site-Specific Advisory Board \\
\hline SWSA & solid waste storage area \\
\hline TDEC & Tennessee Department of Environment and Conservation \\
\hline TOA & Tennessee Oversight Agreement \\
\hline UST & underground storage tank \\
\hline VDRIF & Variable Dose Rate Irradiation Facility \\
\hline $\begin{array}{l}\text { VOC } \\
\text { WAG }\end{array}$ & $\begin{array}{l}\text { volatile organic compound } \\
\text { waste area grouping }\end{array}$ \\
\hline WAG & waste area grouping \\
\hline
\end{tabular}




\section{EXECUTIVE SUMMARY}

This quarterly progress report satisfies requirements for the Environmental Restoration (ER) Program that are specified in the Oak Ridge Reservation (ORR) Federal Facility Agreement (FFA) established between the U.S. Department of Energy (DOE), the U.S. Environmental Protection Agency (EPA), and the Tennessee Department of Environment and Conservation (TDEC). The reporting period covered is October through December 1993 (first quarter of FY 1994).

Sections 1.1 and 1.2 provide respectively the milestones scheduled for completion during the reporting period and a list of documents that have been proposed for transmittal during the following quarter but have not been approved as FY 1994 commitments.

\subsection{DOCUMENTS TRANSMTTTED TO THE REGULATORS}

The following documents were transmitted to the regulators during the first quarter of FY 1994 and are available at the Information Resource Center in Oak Ridge.

- Upper East Fork Poplar Creek (EFPC) Operable Unit (OU) 2 Remedial Investigation (RI) Report (DOE/OR/01-1214\&D1)

- Upper EFPC OU 2 Proposed Plan (DOE/OR/02-1215\&D1)

- Waste Area Grouping (WAG) 5 Seeps Removal Engineering Evaluation/Cost Analysis (DOE/OR/02-1217\&D1)

- WAG 6 Monitoring Plan (DOE/OR/01-1192\&D1)

- WAG 7 Treatability Study (DOE/OR/01-1152\&D1)

- K-1070 SW-31 Spring Phase II Remedial Design Report (DOE/OR/03-1199/V1\&D1 and DOE/OR/03-1199/V2\&D1)

- ORR Site Management Plan for the Environmental Restoration Program (DOE/OR1001/R3)

- K-1407 B \& C Ponds Remedial Design/Remedial Action Work Plan (DOE/OR/011131\&D1)

- K-1407 B \& C Remedial Design Report (DOE/OR/01-1155\&D1)

\section{DOCUMENTS PROPOSED FOR TRANSMITTAL}

The following documents have been proposed for transmittal to the regulators during the second quarter of FY 1994.

- WAG 1 Groundwater Phase II RI Work Plan

- WAG 5 Seeps Action Memorandum 


\section{SIGNIFICANT ACCOMPLISHMENTS}

The following significant accomplishments are noted for the ER Program during the first quartc. of FY 1994.

\section{- Y-12 Plant}

Upper EFPC OU 2. Upper EFPC OU 2 is the Abandoned Nitric Acid Pipeline, which was used between 1951 and 1983 to transport a waste stream made up of nitric acid and depleted uranium from Building 9215 to the S-3 Ponds for disposal. The S-3 Ponds consisted of four unlined surface impoundments that underwent Resource Conservation and Recovery Act (RCRA) closure in 1988. The pipeline was constructed of 1.5- to 3-in.diameter stainless steel pipe and was buried at an average of $5 \mathrm{ft}$ below the ground. Numerous leaks have been suspected, with the earliest in 1951 at a weld about $350 \mathrm{ft}$ east of the discharge point.

As a result of guidance received in working group meetings with the regulators, the Risk Assessment was combined with the Site Characterization Report to create an abbreviated RI Report. This report was issued to the regulators for comment. The Proposed Plan was also issued to the regulators for comment.

The primary exposure pathways evaluated for the Nitric Acid Pipeline are related to potential soil contamination resulting from adsorption from leaked solutions, groundwater contamination resulting from waste solutions infiltrating to the groundwater table, and surface water contamination resulting from groundwater seeps. Nitrate and uranium were the primary contaminants of concern. However, biased soil sampling data collected in the early spring of 1993 do not indicate detectable concentrations of these contaminants, and treatment alternatives for this OU will be proposed to the public during the spring time frame. A comprehensive evaluation of the extent of groundwater and surface water contamination within the watershed will be conducted as part of Upper EFPC OU 1.

Lower EFPC OU. The Lower EFPC OU extends from the outfall at Lake Reality at the Y-12 Plant boundary downstream to the stream's confluence with Poplar Creek. Upper EFPC originates within the Y-12 Plant and extends to the Lake Reality outfall. The Lower EFPC site consists of the 23-km stream and an associated 550-acre floodplain. As a result of the loss to the environment of contaminants associated with lithium processing operations at the Y-12 Plant, EFPC became contaminated with mercury and trace levels of other metals, organics, and radicnuclides. Since 1953, as much as 2.4 million pounds of mercury are thought to have been released. Approximately 75 metric tons of this material may still be in the floodplain soils.

The Sewer Line Beltway was constructed by the city of Oak Ridge during 1982 and 1983 and contains over 10 miles of sanitary interceptor sewers and force mains. In certain instances, EFPC floodplain soils were used to provide topsoil. No records were kept to document the backfill procedures and locations.

Considerable progress was made over the last 3 months as this operable unit has moved forward to a final decision. The draft FS/EIS and draft Proposed Plan were submitted to DOE Headquarters (DOE-HQ) for review and comment. Floodplain soil was excavated for the Low Temperature Thermal Desorption Pilot Demonstration. In the arena of Community Relations, the EFPC Citizen's Working Group continued to provide 
public input into the alternative selection process in the FS. This group continued to thoroughly examine the seven possible remediation alternatives.

The Oak Ridge National Laboratory (ORNL) Environmental Sciences Division continued its study to determine the mechanism of mercury/PCB uptake of periphyton and stoneroller minnows in EFPC. They also started an investigation into determining the chemical form of mercury in the floodplain soils. Sampling and analysis efforts to determine contaminant uptake in wetlands and trees growing within the Lower EFPC floodplain were completed. Analysis results are currently being evaluated. Sediment toxicity studies were also initiated.

\section{- Oak Ridge National Laboratory}

WAG 5. ORNL WAG 5 is comprised of 16 contaminated areas, including LLLW transfer lines and leak sites, hydrofracture surface facilities, waste storage tanks, a sludge basin and a holding pond, a shallow land burial ground containing radioactive and hazardous wastes [solid waste storage area (SWSA) 5 South], and a transuranic waste storage area (SWSA 5 North, which has not yet been transferred to the ER Program). These areas are located east of White Oak Creek, northwest of Melton Branch. SWSA 5 South and North is an area of about 80 acres and was used for disposing of routine buried waste (south side) and transuranic contaminated waste (north side). The major contaminants detected in groundwater seepage have been strontium-90 and tritium.

A Public Notice for the Engineering Evaluation/Cost Analysis associated with a removal action involving two seeps at WAG 5 was published on December 28, beginning the required period of public comment on this report.

WAG 6 ORNL WAG 6 consists of SWSA 6, the Emergency Waste Basin, and the Explosives Detonation Trench. SWSA 6 is located northwest of White Oak Creek ñar White Oak Dam and State Highway 95. This 68-acre site is still in operation as a waste burial ground for solid low-level radioactive waste. Contaminants of concern include various radionuclides and hazardous chemicals.

On December 7, a public meeting regarding this site drew 125 people. A portion of the meeting was devoted to WAG 6. The public was briefed on the revised WAG 6 strategy, a revision prompted by the public's dissatisfaction with the strategy proposed at a public meeting in February 1993. The new strategy includes long-term monitoring with deferred remedial action until improved technologies are available to remedy the site in a cost-effective manner. Feedback from comments received during the meeting and in subsequent press reports were that the new approach was well received.

WAG 10. ORNL WAG 10 is defined as the underground components (i.e., wells, injected grout sheets, and contaminated media) of four different areas located in Melton Valley that were used in the development and full-scale application of hydrofracture operations. The four areas are Hydrofracture Experiment Site 1 (HF-1), Hydrofracture Experiment Site 2 (HF-2), the Old Hydrofracture Facility (also known as HF-3), and the New Hydrofracture Facility (HF-4). Surface facilities associated with the hydrofracture operations are not included in WAG 10. (The surface facilities are considered to be components of ORNL WAGs 5, 7, and 8.)

During the reporting period for this quarterly report, wellhead tapping and sampling activities were begun, and the final WAG 10 OU 3 (Hydrofracture Wells and Boreholes) 
Waste Management Plan; Database Management Plan; and Environmental, Safety, and Health Plan were issued.

WAG 11. ORNL WAG 11 is the White Wing Scrap Yard located at the west end of East Fork Ridge between State Highway 95 (White Wing Road) and the Oak Ridge Turnpike. The unit, which covers -30 acres, was used to store contaminated materials from the three Oak Ridge plants. Wastes (equipment, tanks, and trucks) were thought to have been stored above ground, but additional investigations may prove otherwise. Much of the stored materials and contaminated soil was removed during 1966-1971; however, some scrap metal, concrete, and other waste remain. Contaminants of concern identified to date are gamma radiation, cesium-137, thorium-234, uranium-235, and PCBs.

On November 1, an Interim ROD surface debris cleanup action was begun. To date, ORNL Plant and Equiprent personnel have cleared 71 of a total of 114 grids.

- Oak Ridge K-25 Site

Approval was received from TDEC and EPA on the ROD for the K-1407-B Holding Pond and K-1407-C Retention Basin.

The Remedial Design Report for the K-1407-B and -C ponds was submitted to TDEC and EPA on October 11.

The Remedial Design/Remedial Action Work Plan for the K-1407-B and -C ponds was submitted to TDEC and EPA on October 5.

The Pond Waste Management Project is on hold pending safety reviews resulting from the worker fatality in November 1992. Negotiations with the regulators regarding proposed modifications to the Record of Decision continued. Temporary authorization from TDEC to store raw sludge in K-1065 was received. A Part B Permit Modification that would allow raw sludge in the K-1065 facilities was submitted to TDEC.

- Community Relations

The Community Relations program organized the second annual EnvironMENTAL Fair on October 8 at the American Museum of Science and Energy in Oak Ridge. More than 4,000 area middle-school students, teachers, and museum visitors attended the 9:00 a.m.to-3:00 p.m. event and walked away with an increased understanding of the environmental work under way on the ORR and associated areas and DOE's commitment to environmental stewardship. Approximately 500 community members visited the more than 50 activities during the evening time period. Over $800 \mathrm{DOE}$ and contractor employees, educators, high-school and college students, members of area civic organizations, and nonprofit groups, retirees, and local residents volunteered their time and energy to make this year's fair a rousing success. Considerable advance efforts were employed to tie Fair activities to the schools' science curricula. Student, teacher, and volunteer feedback were overwhelmingly favorable.

An ongoing exercise in focused public participation, involving over two dozen members of the community representing a wide range of opinions, continued to provide valuable input for the development of remedial alternatives for mercury contamination in the sediments and floodplain soils of EFPC Creek. The Citizer.s' Working Group met on October 13, November 3, and December 1. 
Scoping meetings continued on a proposed Site-Specific Advisory Board (SSAB) for the ORR. Consensus on the need for and composition of such a board has thus far proven elusive. Meetings with the stakeholders have been held throughout the summer and fall. At a November 9 meeting, the stakeholders agreed that a 15-member working group should be formed to evaluate an SSAB and make a recommendation regarding such a board to the larger stakeholders group.

A multitopic public meeting was held on December 7. Agenda topics were the following: the WAG 6 revised remedial action plan; the Federal Facility Compliance Act; and DOE's Roadmapping Process (a planning, prioritizing, and public participation tool developed for strategic management of Environmental Restoration and Waste Management programs).

Regulatory Commitment Status

\begin{tabular}{lcc}
\hline \multicolumn{1}{c}{ Document title } & $\begin{array}{c}\text { Appendix E } \\
\text { commitment date }\end{array}$ & $\begin{array}{c}\text { Transmittal } \\
\text { date }\end{array}$ \\
\hline Upper EFPC OU 2 RI Report & $02 / 22 / 94$ & $12 / 04 / 93$ \\
Upper EFPC OU 2 Proposed Plan & $04 / 21 / 94$ & $12 / 16 / 93$ \\
WAG 5 Seeps Removal Engineering & $12 / 01 / 93$ & $12 / 01 / 93$ \\
Evaluation/Cost Analysis & & \\
WAG 6 Monitoring Plan & $10 / 01 / 93$ & $09 / 10 / 93$ \\
WAG 7 Treatability Study & $10 / 01 / 93$ & $09 / 15 / 93$ \\
K-1070 SW-31 Spring Phase II & $11 / 24 / 93$ & $11 / 22 / 93$ \\
Remedial Design Report & & \\
ORR Site Management Plan for ER Program & N/A & $12 / 06 / 93$ \\
K-1407 B \& C Ponds Remedial Design/ & $09 / 30 / 93$ & $10 / 05 / 93$ \\
Remedial Action Work Plan & & \\
K-1407 B \& C Ponds Remedial Design Report & $09 / 30 / 93$ & $10 / 11 / 93$ \\
\hline
\end{tabular}




\section{TECHNICAL STATUS}

\subsection{OAK RIDGE Y-12 PLANT}

The Oak Ridge Y-12 Plant was built by the U.S. Army Corps of Engineers in 1943 as part of the Manhattan Project. The original mission of the Y-12 Plant was to separate the fissionable isotope of uranium $\left({ }^{235} \mathrm{U}\right)$ by the electromagnetic process. After World War II, the electromagnetic separation process was discontinued in favor of the more economical gaseous diffusion process.

Since the early years of the Y-12 Plant operations, the facility has developed into a highly sophisticated manufacturing and developmental engineering facility. It occupies $\sim 800$ acres and is located immediately adjacent to the city of Oak Ridge. The total work force consists of -8000 persons, including employees of ORNL.

The Oak Ridge Y-12 Plant is located on the DOE ORR immediately adjacent to the city of Oak Ridge, Tennessee. Until 1993, the primary mission of the Y-12 Plant was the production and fabrication of nuclear weapon components. Activities associated with these functions included the production of lithium compounds, recovery of enriched uranium from scrap material, and fabrication of uranium and other materials into finished parts. Fabrication operations included vacuum casting, arc melting, powder compaction, rolling, forming, heat treating, machining, inspection, and testing.

Currently, personnel are refocusing the technical capabilities and expertise at the Y-12 Plant to serve the DOE and other DOE-approved customers. The Y-12 Plant is a key manufacturing technology center for the development and demonstration of unique materials, components, and services of importance to DOE and the nation. Specific focus areas for the Y-12 Plant in coming years include: (1) weapons dismantlement and storage; (2) enriched uranium material warehousing and management; (3) nuclear weapons process technology and development support; (4) Y-12 Plant management/landlord activities, including renovating stand-by or shut-down facilities by decontamination and decommissioning (D\&D); (6) providing unique capabilities and technologies not found in the private sector on DOEapproved tasks; (7) transferring technology developed at DOE facilities to enhance our industrial competitive edge in world-wide markets; and (8) maintaining and supporting the National Security Program Office for DOE.

An additional responsibility of the Y-12 Plant is to provide support and assistance to other government agencies whenever time or technology considerations warrant interagency agreements with DOE.

A number of areas of concern have been identified at the $Y-12$ Plant site resulting from past waste management practices. Many of these areas have been grouped into OUs based on priority and common assessment and remediation requirements. Numbers of areas have been grouped into prioritized study areas for additional assessment within the plant boundaries and surrounding environs.

Two OUs have been defined for groundwater and surface water contained within the Bear Creek and Upper EFPC hydrologic regimes. Groundwater will be investigated separately because of the overlapping nature of source plumes and the observation that most plumes 
share a common hydrologic unit for off-site transport. Also, many releases to groundwater are historical, and the resulting plumes are no longer likely to be associated with the original source. As the groundwater plumes are defined, they will be associated with sources to the extent practical. Groundwater contamination in the Chestnut Ridge hydrologic regime is associated with each source OU.

\subsubsection{Upper EFPC OU 1 (Groundwater)}

\section{Description}

Upper EFPC OU 1 consists of both surface water and groundwater components of the hydrogeologic system within the Upper EFPC hydrologic regime. This coupled groundwater and surface water regime is bounded by the crests of Chestnut and Pine ridges and extends east from a topographic high near the west end of the Y-12 Plant to the point where Lake Reality discharges to Lower EFPC. This OU is concerned with the surface water, including minor amounts of sediment in the Upper EFPC channel, and groundwater pathways that have the potential to transport contaminants to off-site receptors.

Surface Water and Groundwater. Numerous sources of contamination to both the surface water and groundwater flow systems exist within the plant area. Infiltration from the S-3 Ponds Waste Management Area dominates groundwater contamination in the western portion of the hydrologic regime. In addition to potential surface water and groundwater contamination sources identified in Upper EFPC OUs 1 and 3, the majority of the potentially contaminated units making up the Y-12 Study Area are within the Upper EFPC hydrologic regime. Potential surface water contamination associated with the Storm Sewer System and Mercury Use Areas is of primary interest and will be addressed in this OU.

Storm Sewer System. The Storm Sewer System consists of an extensive array of storm drains that gather runoff from the main plant area in catch basins located across the plant. In addition, this drainage system, which was once connected to process equipment, discharged untreated waste streams. No untreated waste streams are currently discharged into the storm sewer system. The storm sewer network contains several miles of drainage pipes and culverts that range up to $108 \mathrm{in}$. in diameter. Upper EFPC begins near the middle of the Y-12 Plant and is fed entirely from Storm Sewer System discharges. Surface-water runoff from the Y-12 Plant production areas and groundwater seepage are additional sources of Upper EFPC flow.

Mercury Use Areas. From 1955 through 1963, a column-exchange process involving large quantities of mercury was employed to separate lithium isotopes. The Mercury Use Areas include buildings and other facilities that have been designated as possible sources of mercury contamination because of known, suspected, or presumed releases. The area of investigation includes drainages associated with the following buildings and adjoining areas: 9201-2, 9201-5, 9204-4, 9202, 9733-1, 9733-2, and mercury flask storage areas and deflasking facilities.

Surface water and groundwater within the Upper EFPC hydrologic regime will be characterized and treated as an integrator OU distinct from source term OUs contributing contamination. This approach is warranted because (1) efforts to establish the horizontal and vertical extent of groundwater contaminant plumes from individual areas indicate that the plumes are significantly intermingled, making assessment and potential remedial actions of individual plumes impractical, and (2) the units share a common exit pathway from the hydrologic system, which is best addressed by a comprehensive approach. Where site-specific 
groundwater or surface water data are needed to better identify the source or to support a screening-level risk assessment, groundwater or surface water assessment activities (e.g., piezometers or well points) may be conducted during the RI/FS process for the source-control OUs.

Accomplishments

The dry weather sampling of the Phase I surface water RI effort was completed. Laboratory analysis of the 1,400 water samples is nearing completion, with one of four scheduled data packages being complete.

\section{Concerns}

Concern: Wet weather sampling will be considerably more difficult than the dry weather events. Impact: Costs may be significantly higher than projected. Action: The project team will use lessons learned and provide new estimates of the resources required to complete this work.

\section{Scheduled Activities for Next Quarter}

The results of the dry weather analysis will be reviewed in conjunction with the regulators. Planning for the wet weather sampling events will be initiated.

\subsubsection{Upper EFPC OU 2}

\section{Dascription}

Upper EFPC OU 2 is the Abandoned Nitric Acid Pipeline, which was used between 1951 and 1983 to transport a waste stream made up of nitric acid and depleted uranium from Building 9215 to the S-3 Ponds for disposal. The S-3 Ponds consisted of four unlined surface impoundments that underwent RCRA closure in 1988. The pipeline was constructed of 1.5to 3.0-in.-diam stainless steel pipe and was buried at an average of $5 \mathrm{ft}$ below the ground surface. Numerous leaks have been determined, with the earliest in 1951 at a weld about 350 ft east of the discharge point.

The primary exposure pathways evaluated with the Nitric Acid Pipeline were related to potential soil contamination resulting from adsorption from leaked solutions, groundwater contamination resulting from waste solutions infiltrating to the groundwater table, and surface water contamination resulting from groundwater seeps. Nitrate and uranium were the primary contaminants of concern. However, biased soil sampling data collected in early spring 1993 do not indicate detectable concentrations of these contaminants, and this OU will be proposed as a no further action ROD. A comprehensive evaluation of the extent of groundwater and surface water contamination within the watershed will be conducted as part of Upper EFPC OU 1.

\section{Accomplishments}

As a result of work accomplished in working groups with the regulators, the Risk Assessment has been combined with the Site Characterization Report to create an 
abbreviated RI Report. This has been issued to the regulators for comment. The no further action (NFA) Proposed Plan has been issued to the reguletors for comment.

\section{Concerns}

Concern: The schedule for this project is greatly accelerated. Impact: There may be delays associated with accomplishing milestones if the accelerated review schedule is not met by all parties. Action: The schedule has been identified as a concern to all reviewers. The technical content of the documents has been discussed with the regulators in working group sessions.

\section{Scheduled Activities for Next Quarter}

Comments will be incorporated when they are received. The RI Report and Proposed Plan will be issued for approval. Work will begin on preparing the ROD.

\subsubsection{Upper EFPC OU 3}

\section{Description}

Upper EFPC OU 3 is a source term OU composed of seven areas in the western portion of the Y-12 Plant. For the most part, the Upper EFPC OU 3 areas served unrelated purposes and are geographically removed from one another. The seven areas include Building 81-10, S-2 Site, Salvage Yard Oil Storage Tanks, Salvage Yard Oil/Solvent Drum Storage Area, Tank Site 2063-U, Salvage Yard Drum Deheader, and the Salvage Yard Scrap Metal Storage Area. Three other areas (Waste Coolant Processing Facility, Machine Coolant Storage Tanks, and the Coal Pile Trench) were originally placed in the Upper EFPC OU 3 but have been transferred from the OU to the Upper EFPC study areas. The Coal Pile Trench was removed from the OU because it is located beneath an active Coal Pile; the other areas were removed because they are currently active facilities.

S-2 Site. The S-2 Site is in the southwestern portion of the main Y-12 Plant area, south of Building 9720-32 and on the southern side of Third Street at the base of Chestnut Ridge. The unit was an unlined earthen reservoir that was operated from approximately 1943 to 1951 to dispose of corrosive and toxic liquid wastes generated by the Y-12 Plant. The unit originally consisted of a $45-$ by 128 -ft reservoir that was $\sim 20 \mathrm{ft}$ deep. The reservoir was back-filled, leveled, and stabilized when disposal operations ended during the 1950s. Heavy metals (including mercury in soil), volatile organic compounds, and radioactive chemicals are contaminants of concern.

Building 81-10. The Building 81-10 site is within the Y-12 Plant at the northwest corner of the intersection of " $\mathrm{G}$ " Road and Third Street, south of Upper EFPC. Included as part of the site are two sumps. One sump (Building 9822) is on the east side of " $G$ " Road, and the other sump is $25 \mathrm{ft}$ east of the northeast corner of Building 81-10. Building 81-10 was built in 1943 as a tin shop. In 1957, Building 81-10 was converted for mercury recovery operations by physical separation or distillation by furnace. The furnace was in operation for approximately 5 years, closing in 1962 . Mercury releases associated with handling during physical separation and from furnace operations have been documented. In 1984, the site was used as a storage area to stockpile mercury-contaminated soil. Use of the site to stockpile soil was discontinued and the soil was removed; however, the date of soil removal is unknown. 
Initial assessments of ihe site indicate mercury contamination of soil surrounding the building and storage pad.

Salvage Yard Area The Salvage Yard Area is in the northwestern area of the plant, south of Bear Creek Road and North of Second Street. The Salvage Yard Area is about 11 acres and contains five separate OU 3 areas. The following areas are contained within the Salvage Yard Area.

\section{- Salvage Yard Oil Storage Tanks}

- Salvage Yard Oil/Solvent Drum Storage Area

- Salvage Yard Drum Deheader

- Salvage Yard Scrap Metal Storage Area

- Tank 2063-U Site

Salvage Yard Oil Storage Tanks. The Salvage Yard Oil Storage Tanks consist of two tanks surrounded by a rip-rap earthen dike in the northwest corner of the Salvage Yard Area. Waste oils stored in the Salvage Yard Oil Storage Tanks were generated by various operations within the Y-12 Plant. The southern tank with a capacity of 6000 gal was put into service in 1978 and stored automotive crankcase oils, vacuum pump oils, hydraulic systems, and machining oils. The northern tank with a capacity of $5000 \mathrm{gal}$ was put into service in 1980 and contained mineral oils generated from transformer oil changeout. In 1986 use of the tanks were discontinued, and their contents were emptied. The tanks are still at the site and contain bottom sludges contaminated with polychlorinated biphenyls (PCBs) and chlorinated solvents.

Salvage Yard Oilsolvent Drum Storage Area. The Salvage Yard Oil/Solvent Drum Storage Area is in the northwest portion of the Salvage Yard and operated from 1976 to 1989. It has since been closed under RCRA. Originally, the drum storage area consisted of 2 compacted gravel areas on top of soil. Each area had a dike constructed of clay and gravel on the downgradient side. The combined storage are had a capacity of up to 175,000 gal of drummed waste oils and solvents. These drums rested on pallets and contained waste oils contaminated with chlorinate organics, uranium, and/or beryllium; chlorinated organic solvents; and nonchlorinated flammable solvents. In 1986 the western dike portion was closed and approved by the Tennessee Department of Health and Environment (now TDEC). No soil removal was required to satisfy closure criteria. Closure of the eastern pnrtion began in 1988, when soil was removed to a depth of 1 to $2 \mathrm{ft}$ and replaced with clean clay backfill and covered with a polyethylene membrane. The closure was approved by Tennessee Department of Health and Environment after soil and groundwater analysis data showed arsenic below ORR background levels and PCBs below the health based criteria values. The are is included in OU 3 until completeness of closure can be determined and, if appropriate, no further action can be pursued.

Salvage Yard Drum Deheader and Tank 2063-U Site. The Salvage Yard Drum Deheader is in the northwest portion of the Salvage Yard and operated from 1959 until 1989. It was used to cut the tops off empty drums that had contained oils and solvents. Operations of the drum deheader ceased in March 1989, and all drums have since been removed. The drum deheader and crusher were removed from the site in 1991. Residual materials present in the drums at the time of crushing was transferred to the Tank 2063-U site. This site was used to 
store the liquid waste until it could be removed and treated elsewhere at the Y-12 Plant. Tank 2063-U consisted of 3 concrete and cinder block tanks and were separated by a rubber baffle for water separation. In March 1989, the tanks failed a hydrostatic hold test and were excavated under federal underground storage tank regulations in July 1989. The excavated soil was returned to the pit after a plastic geomembrane liner was installed. Possible contaminants at the drum deheader include volatiles, PCBs, and heavy metals.

Salvage Yard Scrap Metal Storage Area. The Salvage Yard Scrap Metal Storage Area has been operating in the northwestern portion of the Y-12 Plant since 1950, when it was used solely for storage of uranium-contaminated and noncontaminated scrap metal. Visual evidence of surface soil contamination has been observed on aerial photographs taken over the past few years. Soil Contamination resulting from uranium-contaminated salvage materials is of primary concern at this site.

\section{Accomplishments}

Comments on the RI Work Plan were received from the regulators and are being incorporated. Responses to the comments are also being prepared.

\section{Concerns}

Concern: Comments from TDEC reflect the desire to conduct a workshop on data quality objectives (DQOs). Impact: The pursuit of a full DQO process at this stage in the project could cause schedule delays. Action: The project team will work with the regulators to implement a modified DQO process and investigate options for maintaining the schedule.

\section{Scheduled Activities for Nat Quarter}

Comments will be resolved and submitted by January 31, 1994.

A DQO workshop will be conducted.

Contracts on field sampling work will be finalized.

\subsubsection{Bear Creek OU 1}

\section{Description}

Bear Creek OU 1 comprises the following units: S-3 Ponds, Oil Landfarm Waste Management Area, and Burial Grounds Waste Management Area. The Oil Landfarm Waste Management Area consists of the Oil Landfarm Hazardous Waste Disposal Unit, Sanitary Landfill I, the Boneyard/Burnyard, and the Chemical Storage Area. The Burial Grounds Waste Management Area consists of Burial Grounds A, B, C, D, E, and J and Oil Retention Ponds 1 and 2 . These units were used until the 1980s as the primary area for the disposal of various types of hazardous and nonhazardous wastes generated at the Y-12 Plant.

S-3 Ponds. The S-3 Ponds are part of the S-3 Waste Management Area. They were constructed in 1951 and consisted of four unlined surface impoundments covering an area of roughly $\mathbf{4 0 0} \mathrm{ft}$ on each side with a total storage capacity of about $\mathbf{1 0}$ million gal. During its operation, up to $5500 \mathrm{gal} / \mathrm{d}$ of effluent was pumped to the pond. Primary contaminants were 
nitrates and uranium, with lesser concentrations of heavy metals and organic solvents. In 1988, the S-3 Ponds were closed as a RCRA landfill. An asphalt parking lot was constructed over the cap to compete site closure.

Oil Landfarm Hazardous Waste Disposal Unit. The Oil Landfarm Hazardous Waste Disposal Unit was used for the land application of waste oils and coolants that contained beryllium compounds, depleted uranium, PCBs, and chlorinated organic compounds. Disposal operations were discontinued in 1982. In 1990, the site was closed as a landfill with a multilayered engineered cap.

Sanitary Landfill I. Sanitary Landfill I received various types of nonhazardous waste from the Y-12 Plant. Waste disposal at Sanitary Landfill I was terminated in 1982, and the site was graded, capped, and closed in 1983 in accordance with TDEC regulations for sanitary landfills.

Boneyard/Burnyard. The Boneyard/Burnyard consists of $\sim 8$ acres used from 1943 to 1970 as a disposal site for waste from the Y-12 Plant. Burning and disposal of debris and sanitary, metallir, chemical, and radioactive wastes are kuown to have occurred. The site has been abandoned and is predominately covered with grassy vegetation.

Chemical Storage Area. The Chemical Storage Area overlays the southeastern portion of the Burnyard/Boneyard. The Chemical Storage Area was $\sim 2$ acres in size and was used to burn or neutralize liquid and gaseous wastes from 1975 until 1981. The Chemical Storage Area is presently covered with a RCRA-type cap.

Burial Grounde. Burial Grounds A, B, C, D, E, and J, located on the southern slope of Pine Ridge -2 miles west of the Y-12 Plant covers an area of about 5000 by $3000 \mathrm{ft}$. Each disposal unit consists of a series of trenches excavated to depths of 14 to $25 \mathrm{ft}$ below grade. The trenches received a variety of hazardous and nonhazardous solid and liquid wastes. All hazardous waste disposal operations were discontinued in 1981. All trenches known to have received RCRA hazardous material have been capped as part of a RCRA closure.

Oil Retention Ponds. Oil Retention Ponds 1 and 2 were constructed to intercept seepage from burial trenches. Both ponds were RCRA-closed in 1990. A wide range of contaminants may have been disposed of in the Bear Creek Burial Grounds. Volatile organic compounds in soil resulting from groundwater transport are of primary concern.

The nature and extent of. soil contamination within each of the listed units in Bear Creek OU 1 and the nature and extent of sediment and surface water contamination within each associated tributary to Bear Creek will be determined during the Comprehensive Environmental Response, Compensation, and Liability Act (CERCLA) investigation.

\section{Accomplishments}

None. 


\section{Concerns}

Concerm: A health and safety concern related to drilling or digging through hazardous or radioactive waste exists at the Bear Creek Burial Grounds and to a lesser extent at the S-3 Ponds because of many uncertainties at these sites. Impact: Investigations will focus on the periphery of the sites. Action: Existing waste inventory data will be used as the primary source of site characterization for the Burial Grounds.

\section{Scheduled Activities for Next Quarter}

Regulator comments on the draft RI Work Plan will be resolved and incorporated. A response to the comments will be provided to tne regulators.

\subsubsection{Bear Croek OU 2}

\section{Description}

Bear Creek OU 2 consists of the Rust Spoil Area, Spoil Area 1, and the SY-200 Yard.

Rust Spoil Area. The Rust Spoil Area is located in Bear Creek Valley less than 0.5 mile west of the Y-12 Plant on Old Bear Creek Road. The Rust Spoil Area was used from 1975 to 1983 for disposal of spoil material generated during various renovation, maintenance, and construction operations at the Y-12 Plant. Disposed material was periodically graded, resulting in changes in topography and in filling of part of the Bear Creek channel. Approximately $100,000 \mathrm{yd}^{3}$ of nonuranium-contaminated construction spoils were disposed of at the site. Small quantities of solvent-contaminated material and material containing asbestos, mercury, and uranium may have been disposed of in this area. Soil contamination is of primary concern.

Spoil Area 1. Spoil Area 1 is located near the southwest end of the Y-12 Plant, bounded by Old Bear Creek Road and West Patrol Road. Spoil Area 1 was used for the disposal of $-100,000 \mathrm{yd}^{3}$ of nonhazardous, nonradiologically contaminated construction debris. Although plant controls eliminated the disposal of hazardous and radioactive wastes, past plant practices indicate that some of the construction material may have been contaminated with trace amounts of asbestos, mercury, beryllium, thorium, and uranium.

SY-200 Yard. The SY-200 Yard is a 200- by 300-ft aboveground storage area located adjacent to Old Bear Creek Road. Materials from several Y-12 and ORNL divisions included PCB transformers, lead shielding plates, and radioactively contaminated materials. Soil contamination is of primary concern.

\section{Accomplishments}

Field sampling was conducted through December 1993. The project is on schedule to meet an FFA milestone for completion of field sampling by January 31, 1994.

\section{Concerns}

None. 
Scheduled Activities for Next Quarter

Data analysis and validation will be completed.

Work on the RI Report and FS will begin.

\subsubsection{Bear Creek OU 4 (Groundwater)}

\section{Description}

The hydrologic system at the Y-12 Plant has been subdivided into three distinct hydrologic regimes based on topography, surface-water drainage, and groundwater flow. Bear Creek OU 4 addresses contamination within the coupled groundwater/surface water system and floodplain sediments. The area of interest within Bear Creek Valley extends west from a topographic high near the west end of the Y-12 Plant (S-3 Waste Management Area) to the point where Bear Creek exits the valley near State Highway 95. Potential sources of groundwater, surface water, and sediment contamination are being addressed in Bear Creek OUs 1 and 2.

Groundwater and surface water within the Bear Creek hydrologic regime will be characterized and remediated as an integrator OU distinct from the contaminated units. This approach is warranted because (1) efforts to establish the horizontal and verticel extent of groundwater contaminant plumes from individual sites indicate that the piumes are significantly intermingled, making assessment and remediation of individual plumes impractical, and (2) the sites share a common exit pathway from the hydrologic system that is best addressed by a comprehensive approach. Where site-specific groundwater or surface water data are needed to better identify the source or to support a screening-level risk assessment, groundwater or surface water assessment activities (e.g., monitoring wells, piezometers, or well points) may be conducted during the RI/FS process for the source control OUs. The primary groundwater contaminants in the Bear Creek hydrologic regime are nitrates, volatile organic compounds (VOCs), radionuclides, and to a lesser extent, trace metals. Dense, nonaqueous-phase liquids (DNAPLs) have been discovered at a depth of 270 $\mathrm{ft}$ below the Bear Creek Burial Grounds. The DNAPLs consist primarily of perchloroethylene, trichloroethylene, 1,1,1-trichloracetic acid, and high concentrations of PCBs.

\section{Accomplishments}

The Phase I RI Work Plan was issued to the regulators and approved. OU 4.

The FFA Appendix C was modified to incorporate Bear Creek OU 3 into Bear Creek

\section{Concerns}

None. 
Scheduled Activities for Next Quarter

Field sampling activities will begin.

The installation of Westbay Monitoring equipment will be completed.

\subsubsection{Cheatnut Ridge OU 1}

\section{Description}

Chestnut Ridge OU 1 is the Chestnut Ridge Security Pits Hazardous Waste Disposal Unit located on the crest of Chestnut Ridge, southeast of the central portion of the Y-12 Plant. Operated since 1973, the unit consists of a series of trenches that were used for the disposal of classified hazardoiss and nonhazardous wastes until December 1984 and November 1988, respectively. Ten major categories of unclassified wastes have been identified: acids, fiberglass, beryllium, biological material, debris, heavy metals, inorganics, organics, thorium, and uranium. Other classified waste forms are present. The unit was closed in 1988 in accordance with a TDEC-approved closure plan consisting of a low-permeability, low-maintenance cover over the trenches. Groundwater impacts from the disposal operations are the primary focus of this OU.

Accomplishments

None.

\section{Concerns}

None.

\section{Scheduled Activities for Next Quarter}

Regulator comments on the draft RI Work Plan will be resolved and incorporated. A response to comments will be provided to the regulators.

\subsubsection{Chestnut Ridge OU 2}

\section{Description}

Chestnut Ridge OU 2 consists of the Filled Coal Ash Pond and Upper McCoy Branch. The Filled Coal Ash Pond is situated within the McCoy Branch watershed about 0.i5 miles south of the Y-12 Plant. The pond was constructed in 1955 to serve as a settling bisin for coal ash from the Y-12 steam plant. By 1967, the pond filled, spilling sediments direcily into McCoy Branch. From 1967 to 1989, ash was carried within McCoy Branch to Rogers Quarry, about 0.5 mile downstream of the Coal Ash Pond.

Impacts to surface water, stream sediments, and groundwater from metals, including uranium and major ions, are of concern. Biomonitoring of aquatic organisms in McCoy Branch and Roger's Quarry has shown a biological impact potentially from the ash pond operations. 


\section{Accomplishments}

Data analysis and validation for the Phase II field investigation were completed. Work on the RI Report and FS began.

\section{Concerns}

None.

\section{Scheduled Activities for Next Quarter}

Work on the RI Report and FS will continue.

Alternatives will be available for presentation to the EPA and TDEC in order to reduce the number of alternatives to be carried forward in the FS. The draft FS will be nearing completion in order to meet the FFA deliverable date in August 1994.

\subsubsection{Chestnut Ridge OU 4}

\section{Description}

Chestnut Ridge OU 4 consists of Rogers Quarry and Lower McCoy Branch. Rogers Quarry is situated within the McCoy Branch watershed about 1 mile south of the Y-12 Plant. The quarry, which is approximately $1150 \times 250 \times 275 \mathrm{ft}$, was the source of construction materials in the 1940 s and 1950 s. The quarry filled witb water and was abandoned with quarrying equipment in place in the early 1960 s. Disposal of flyash and bottom ash from the $Y-12$ steam plant into the quarry began in the 1960 s, and bottom ash continues to be disposed of in the quarry via a sluice pipe across Chestnut Ridge. The quarry was also used for disposal of other plant process materials.

Lower McCoy Branch begins at the surface water discharge point of Rogers Quarry and ends at the McCoy Branch embayment in the Clinch River/Melton Hill Lake.

Impacts to surface water, stream sediments, and groundwater from metals, including uranium and major ions, are of concern. Biomonitoring of aquatic organisms in Rogers Quarry has shown a biological impact potentially from ash disposal operations.

\section{Accomplishments}

None. 'There will be no work done on Chestnut Ridge OU 4 in FY 1994 due to funding constraints.

\section{Concerns}

None.

\section{Scheduled Activities for Next Quarter}

None. 


\subsubsection{Lower BFPC OU}

The Lower EFPC OU extends from the outfall at Lake Reality at the Y-12 Plant boundary downstream to the stream's confluence with Poplar Creek. Upper EFPC originates within the Y-12 Plant and extends to the Lake Reality outfall. The Lower EFPC site consists of the 23-km stream and an associated 550-acre floodplain.

Ar a result of the loss to the environment of contaminants associated with lithium processing operations at the Y-12 Plant near Oak Ridge, Tennessee, EFPC became contaminated with mercury and trace levels of other metals, organics, and radionuclides. Since 1953, as much as 2.4 million pounds of mercury are thought to have been released. Approximately 75 metric tons of this material may still be in the floodplain soils.

The Sewer Line Beltway was constructed by the city of Oak Ridge during 1982 and 1983 and contains over 10 miles of sanitary interceptor sewers and force mains. In certain instances, EFPC floodplain soils were used to provide topsoil. No records were kept to document the backfill procedures and locations.

\section{Accomplishments}

Floodplain soil was excavated for the Low Temperature Thermal Desorption Pilot Demonstration.

The EFPC Citizens' Working Group continued to provide public input for the alternative selection process in the FS. The group continued to thoroughly examine the seven possible remediation alternatives.

The Environmental Sciences Division, ORNL, continued its study to determine the mechanism of mercury/PCB uptake of periphyton and stoneroller minnows in EFPC. Personnel also started an investigation into determining the chemical form of mercury in the floodplain soils.

Radian and Science Applications International Corporation (SAIC) completed the sampling and analysis effort to determine contaminant uptake in wetlands and trees growing within the Lower EFPC floodplain. The results of the analysis are being evaluated. Sediment toxicity studies were initiated.

\section{Concerns}

None.

\section{Scheduled Activities for Next Quarter}

Meetings will continue with the Citizens' Working Group.

The D2 version of the RI Report will be sent to EPA and TDEC for approval.

The FS/EIS will be submitted to EPA and TDEC for their review and approval.

EFPC floodplain soil will be shipped to vendors to begin the pilot demonstration. 
The analytical results from the sediment toxicity and mercury separation should be received.

\subsubsection{Reduction of Mercury in Plant Effluents (RMPE)}

\section{Description}

The RMPE subproject has undergone a major rescoping activity to define projects required to support the Clean Water Act, National Pollutant Discharge Elimination System (NPDES), requirement. The formal baseline change proposal is currently being submitted. Completed projects have been removed from the project description, and the new project scope consists of the Mercury Use Building Source Elimination and the Mercury Treatment Facility.

Mercury Use Building Source Elimination. Mercury-contaminated storm drains and sumps in the Mercury Use Building-which consists of buildings 9201-2, 9201-4, 9201-5, and 9204-4-will will be bypassed by the installation of new piping that will provide for a clean transport of water from the building. This activity will be conducted in a phased manner.

Mercury Treatment Facility. A new on-line effluent treatment process will be installed to remove mercury from the Y-12 Plant storm water. The design is for a small-scale filtration process with associated pumps and piping to collect the contaminated sump water from Outfall 49 and Outfall 55 for treatment. The mercury-contaminated waters from the Mercury Use Building sumps (9201-2, 9201-4, 9201-5, and 9204-4) will be collected, and long-term treatment will be performed at the Mercury Treatment Facility. The facility will be housed at the existing Central Pollution Control Facility (CPCF). The facility will replace the interim treatment unit(s) once the facility is on-line.

\section{Accomplishments}

Work began on the conceptual design for the Mercury Treatment Facility. The interim unit of carbon filters is being installed for $\mathbf{9 2 0 1 - 2}$ sumps. Additional requirements for interim units will be determined.

Comments from both state and EPA regulators on the Postconstruction Report for the Mercury Tanks Interim Action were received.

More detailed investigations of the Mercury Use Building sumps and piping systems began. Work began on developing the Sampling Plan for the mercury use buildings and associated sumps and piping systems (i.e., for the scurce elimination activity).

The certified for construction package for the source elimination effort at 9201-2 was submitted.

Testing of ion exchange resins and carbon filters for the treatment facility continued.

NPDES compliance schedules for the RMPE project were presented to the state. The proposed compliance projects are tied to achieving the site-specific criteria for mercury previously submitted. These schedules will be the regulatory driver for this project. 


\section{Concerns}

Concern: An NPDES permit is currently being negotiated for the Y-12 Plant that may contain mercury limits that are not attainable due to the nature of contamination at the plant. Impact: The Y-12 Plant and ER Program could be issued a permit that would result in numerous noncompliances. Action: The project team has presented a compliance strategy to TDEC that involves a site-specific criterion for mercury and a plan for reductions in loading to EFPC to achieve the site-specific number.

\section{Scheduled Activities for Next Quarter}

Work on design activities for the Mercury Treatment Facility subproject will continue. The Title I and II design should begin in the second quarter of FY 1994.

The data collection phase of the evaluation of the Mercury Use Building will continue in the next buildings. Source elimination construction work in $\mathbf{9 2 0 1 - 2}$ should be in the field.

The interim solution for outfalls 49 and 55 will continue along with some additional rerouting to reduce contaminated flows. This work will involve installation, testing, and checkout of the interim treatment units.

\subsubsection{RCRA Closures}

\section{Description}

This subproject consists of three areas: (1) the Building 9409-5 Tank Storage Facility; (2) the Garage Underground Storage Tanks (USTs); and (3) the Interim Drum Yard.

YS-017 Building 9409-5 Diked Tank Storage Facility. The Building 9409-5 Diked Tank Storage Facility is a RCRA outdoor, concrete, diked area having a capacity of $-238,000$ gal. This facility was constructed in 1942 as a four-cell cooling tower basin, but it was modified in 1980 for use as a secondary containment facility for tanks and drums of liquid waste. These tanks and drums have contained, at various times, liquid waste coolant, solvents, and waste oils, all of which may have contained PCBs. Some of the waste liquids stored in this facility were known to have contained uranium and beryllium. Chromium may be present as a result of the water treatments used during cooling tower operations. All tanks have been removed from the facility, and the closure plan has been submitted. Approval is pending for all three sites.

YS-019 Garage Underground Tanks. The Garage USTs were part of an on-site facility for servicing motor vehicles. This facility included a gas station with associated underground fuel tanks, underground piping, dispensing pumps, a building, and ancillary fixtures. Two tanks were previously used to store unleaded gasoline (a 20,000-gal tank) and leaded gasoline (a 10,000-gal tank). The tanks were subsequently diverted from their initial use to the storage of waste oils containing the spent solvents perchloroethylene and Freon-113 and measurable quantities of PCB and uranium. A third empty tank in the same dirt emplacement with the two RCRA tanks contained waste oil that was not hazardous under current regulations. 
Surface soil shows evidence of spills/leaks that occurred during sampling and transfer operations. These tanks were originally gasoline storage tanks and were later converted to store the following:

Largest tank: unleaded gasoline, 1975 to 1979

waste oil, 1980 to present

Smaller tanks: gasoline, 1962 to 1979

waste oil, 1980 to present

Clean closure of the tanks began in 1988 by the excavation and decontamination of the tanks, sampling of surrounding soil, and removal of contaminated soil.

YS-030 Interim Drum Yard The Interim Drum Yard west of Building 9720-32 is a RCRA outdoor tented storage facility for containerized hazardous waste. Drums are stored on wooden pallets placed on gravel lined with a plastic tarp covering native soil.

Wastes stored at the facility consist of mercury, metals, ACN, methylene chloride, organics, Freon-113, cyanide, PCBs, uranyl nitrate, penetrant solution and emulsifiers, asbestos, and sodium hypochlorite.

Soil sampling has indicated that the underlying surface soil and gravel were contaminated.

The facility is due to be closed under CERCLA, at which time all wastes stored in the yard will be removed. A small area of the south side was previously closed. Soil contamination at the northern part of the drum yard will be addressed at closure.

Accomplishments

All of the three contaminated tanks that are part of the Garage USTs subproject have now been cleaned and removed from the site. The Closure Plan is in the public comment stage.

Subproject negotiations on field sampling were completed for the Interim Drum Yard and the Diked Tank Storage Area.

\section{Concerns}

Concern: Strict compliance with the RCRA program could result in remediation of lowpriority sites in a fashion that does not integrate with CERCLA activities. Impact: Costly remediation could be driven that does not achieve risk reduction or acknowledge surrounding contamination. Action: Wording has been added to closure plans to transfer remediation authority to CERCLA, and the project team has made regulators aware of the situation. 
Scheduled Activities for Neut Quarter

The remaining closure activities on the Garage USTs subproject will be initiated.

\subsubsection{Rust Fuel Facility}

\section{Description}

The Rust Fuel Facility is located in the western end of the plant and originally consisted of three steel underground tanks in a single bay north of Building 9831 and a smaller tank south of Building 9720-15. These tanks consisted of one 12,000-gal diesel tank and a 12,000and an 8000-gal gasoline tank. The tank south of Building 9720-15 contained 1000 gal of gasoline. The leakage of these tanks and connecting pipeline is well documented. The tanks, piping, and all free liquid gasoline have been removed and disposed of. Clean closure will be accomplished in accordance with UST regulations by excavation and decontamination of affected soil, which will then be returned to the approximate original contour.

\section{Accomplishments}

Additional soil sampling has been performed to better define the extent of the contamination plume. The design has progressed to the $60 \%$ level.

\section{Concems}

None.

\section{Scheduled Activities for Next Quarter}

The architect-engineer design will be completed.

\subsubsection{Study Areas}

\section{Description}

The Study Areas of Upper EFPC consist of $\sim 180$ individual sites within the Y-12 Plant that have been identified as having the potential of containing or having contained one or more hazardous substances or materials. The preponderance of these sites lie in the western exclusion area of the plant.

The scope of work is currently defined as those tasks required to conduct Preliminary Assessments and Site Investigations (PASIs) of all sites to determine if further action is necessary under one of the existing OUs. For those sites requiring further action, the balance of the CERCLA process of RI, FS, and remedial action, as necessary, will be conducted.

It is anticipated that $-60 \%$ of these sites will be determined to require "no further investigation" subsequent to the conclusion of a formal PASI. The balance of the sites are expected to be subject to the CERCLA process. 
As the PASIs progress and more information is accumulated and assimilated relative to the current and historic operations in selected areas of the plant, it is anticipated that there will be additions to and deletions from the list of sites for this activity.

Accomplishments

A PA Report for the Y-12 Plant has been issued for internal comment.

\section{Concerrss}

None.

\section{Scheduled Activities for Next Qxarter}

The top 25 study areas will be identified on the basis of the prioritization methodology and historical evidence. SI Plans will be initiated on six of these sites.

\section{OAK RIDGE NATIONAL LABORATORY}

ORNL occupies -3560 acres in Melton Valley and Bethel Valley, 10 miles southwest of downtown Oak Ridge, Tennessee. ORNL's mission is to conduct applied research and engineering development in support of DOE programs in nuclear fusion and fission, energy conservation, fossil fuels, and other energy technologies and to perform basic scientific research in selected areas of the physical, life, and environmental sciences. The laboratory was built in 1943 as part of the World War II Manhattan Project. Its original mission was to produce and chemically separate the first gram quantities of plutonium as part of the national effort to produce the atomic bomb. ORNL's remediation sites are organized into WAGs based on drainage area and similar waste characteristics.

\subsection{ORNL WAG 1}

\section{Description}

ORNL WAG 1 consists of 96 individual contaminated areas requiring, or potentially requiring, remediation. The unit consists of low-level liquid waste collection and storage tanks; leak and spill areas and contaminated soils; ponds and impoundments; waste treatment facilities; shallow land burial and other SWSAs; and other miscellaneous chemical and sanitary waste facilities. These areas are located in the main plant area. A variety of contaminants of concern, including radionuclides, heavy metals, and organics, are present within this WAG.

WAG 1 has been broken into ten OUs to address the concerns within the ORNL operations area.

\section{Accomplishments}

Work was initiated on the RI Report for the surface impoundments OU. An observational approach workshop was conducted with EPA and TDEC on December 8. 
The RI/FS Report on the Gunite and Associated Tanks OU in WAG 1 was completed for peer review.

\section{Concems}

None.

\section{Scheduled Activities for Next Quarter}

The RI/FS Report on the Gunite and Associated Tanks OU will be issued.

EPA and TDEC approval of a letter agreement documenting the decision to proceed with an RI/FS Report for the surface impoundments OU should be received in January. Jacobs Engineering will then initiate the FS process.

The WAG 1 Groundwater Phase II RI Work Plan will be submitted to EPA and TDEC for review.

\section{Inactive Liquid Low-Level Radioactive Waste Tanks}

\section{Description}

Liquid low-level radioactive wastes have been collected at ORNL since 1943 i I tank systems used for storage, transfer, and neutralization. Some of the tanks have been renloved from service and are no longer in use. The majority of these tanks are owned by ER and are in the CERCLA remediation process. However, a few of these tanks are owned by W/aste Management and LLLW generators. These remaining tanks are in the process of being transferred to ER. Liquids and sludges remain in many of the tanks, with several tanks receiving inleakage from rainwater. The tanks are located in various WAGs but primarily in WAGs 1 and 5.

\section{Accomplishments}

None.

\section{Concerns}

Concern: A request to return tank W-12 to active service following the installation of a new discharge line was denied. Impact: Decontamination of Building 3525 has been delayed due to lack of LLLW tank access. Action: A request will be submitted for one-time use of tank W-12 to support the decontamination and reduce the potential risk of environmental impact and personnel exposure.

\section{Scheduled Activities for Next Quarter}

An information package on the waste content of Tank WC-14 will be submitted.

A request for one-time use of inactive Tank WC-8 in support of the WC-9 discharge system installation will be submitted. 
A justification and request for the one-time use of Tank W-12 to support decontamination activities in Building 3525 will be submitted.

\subsection{Active Liquid Low-Level Radioactive Waste Tank}

Description

Although the FFA addresses the entire ORR, specific requirements are set forth for the LLLW tanks at ORNL. Liquid low-level radioactive wastes have been collected at ORNL since 1943 in tank systems used for storage, transfer, and neutralization. The stated objective of the FFA as it relates to the tank systems is to ensure structural integrity, containment, detection of releases, and source control pending final remedial action at the site. The FFA requires that leaking LLLW tank systems be immediately removed from service. It also requires that LLLW tank systems that do not meet the design and performance requirements established for secondary containment and leak detection be either upgraded or replaced.

\section{Accomplishments}

Leak testing methodology demonstrations continued for the remaining active singlycontained tanks and piping systems.

\section{Concerns}

None.

\section{Scheduled Activities for Next Quarter}

A response to comments on the design demonstrations for 11 Category B tank systems will be submitted (DOE/OR-1047\&D1).

A response to comments on the design demonstrations for the remaining 19 Category $B$ tank systems will be submitted (DOE/OR-1150\&D1).

A response to comments on the detailed leak detection test plan and schedule for active pipelines will be submitted (DOE/OR-1167\&D1).

A document describing an active LLLW tanks design/installation assessment for FFA compliance work, Building 3019A, will be issued to the regulators.

\subsection{ORNL WAG 2 (White Oak Creek Embayment/Tributariea/Soil OU 1)}

\section{Description}

White Oak Creek and its tributaries are located in Melton and Bethel Valleys. White Oak Creek flows into the Clinch River about 1.5 miles north of the junction of Interstate 40 and State Highway 95. White Oak Lake is located upstream of White Oak Lake Dam, south of the ORNL main complex. The dam was built 0.6 mile upstream from where White Oak Creek empties into the Clinch River (mile 20.8, CRK 33.5). White Oak Creek Embayment encompasses the area downstream of White Oak Dam to the confluence of White Oak Creek with the Clinch River. White Oak Lake is a surface impoundment for radioactive and other 
hazardous wastes that drain from ORNL via the White Oak Creek watershed. It serves as a final settling basin for waste released from ORNL operations and waste storage areas. The White Oak Creek drainage system has been contaminated since activities at the ORNL site began in 1943. Main contaminants identified to date are ${ }^{90} \mathrm{Sr},{ }^{137} \mathrm{Cs},{ }^{60} \mathrm{Co},{ }^{3} \mathrm{H}$, and metals (mercury, zinc, arsenic, and chromium). Hazardous organic chemicals, including PCBs, may also be present in the stream and lake sediments.

\section{Accomplishments}

Water quality sampling was conducted at the major flow stations in the White Oak Creek watershed during the December 4 storm and the following 3 days. The storm was judged to have a 5-jear return period. Over 500 samples were collected to obtain information about contaminant sediment flux in the watershed and to assist in the calibration of the hydrologic simulation model used in selecting and evaluating remedial alternatives.

Bimonthly samples were taken from seep, tributary, and main stream locations in the White Oak Creek watershed. The samples will be analyzed primarily for radionuclides to further elucidate contaminant fluxes from key source areas and to examine seasonal effects on contaminant transport. Other sampling locations were added in the vicinity of the WAG 1 impoundments for the purpose of investigating the ${ }^{90} \mathrm{Sr}$ influx from the impounciments to White Oak Creek.

Staff gauges were placed at White Oak Creek Embayment on the Clinch River. Thes gauges (one upstream of the coffer cell dam and one downstream) will be used to calibrate flows past the coffer cell dam structure. These data will support quantification of contaminant fluxes from ORNL.

\section{Concerms}

None.

\section{Scheduled Activities for Next Quarter}

Routine field sampling/field characterization and monitoring activities will continue.

\section{ORNL WAG 4}

WAG 4 is located in Melton Valley immediately south of the main plant area through a gap in Haw Ridge. This WAG is comprised of three OUs: (1) a shallow land burial ground containing radioactive and hazardous wastes; (2) two pilot-scale LLLW waste seepage pits; and (3) an underground pipeline used to transfer liquid radioactive wastes from the main plant area to waste pits and trenches (WAG 7).

\section{Accomplishments}

Prepared a WAG 4 data summary report, which is an assessment of the current environmental conditions at WAG 4. Plans are to use the data in this report to support potential remedial strategies Juring a regulatory scoping meeting. 


\section{Concens}

None.

\section{Scheduled Activities for Next Quarter}

A regulatory scoping meeting will be conducted for the purpose of assessing and evaluating the information contained in the WAG 4 data summary report.

\subsubsection{ORNL WAG 5}

\section{Description}

ORNL WAG 5 is comprised of 16 contaminated areas, including LLLW transfer lines and leak sites, hydrofracture surface facilities, waste storage tanks, a sludge basin and a holding pond, a shallow land burial ground containing radioactive and hazardous wastes (SWSA 5 South), and a transuranic waste storage area (SWSA 5 North, which has not been transferred to the ER Program at this time).

These areas are located east of White Oak Creek, northwest of Melton Branch. SWSA 5 South and North is an area of $\sim \mathbf{8 0}$ acres and was used for disposing of routine buried waste (south side) and transuranic contaminated waste (north side). The major contaminants detected in groundwater seepage are ${ }^{90} \mathrm{Sr}$ and ${ }^{3} \mathrm{H}$.

\section{Accomplishments}

Approval of the Ecological Assessment Plan was received from the regulators.

The installation of drive point wells in support of the focused seep investigation was completed for all seep areas except seep area D.

The dry season sampling event was completed; the laboratory analysis and validation are in progress.

Activities in seep area $\mathbf{C}$ designed to enhance seep flow monitoring and sampling were begun. Measures to divert surface water run-on from surrounding areas were completed. The installation of the temporary flume was initiated. Additional work planned includes installation of the data logger, transducer, and ISCO sampler.

The Engineering Evaluation/Cost Analysis for the removal action for seep areas $\mathrm{C}$ and D was completed.

The Public Notice for the Engineering Evaluation/Cost Analysis for the seeps removal action was published on December 28 , and the public comment period was initiated.

The set up of equipment associated with the study of zeolite treatment for strontiumcontaminated surface water at seep area $\mathrm{C}$ was completed. 
Concerns

None.

Scheduled Activities for Next Quarter

The RI for WAG 5 will continue, and work will begin on developing the RI Report for this WAG. A focused seep area investigation will continue. The installation of deep wells and drive point wells will be completed.

Public comments will be incorporated, and the final Engineering Evaluation/Cost Analysis for the removal action for the seeps will be issued on February 10, 1994.

The Action Memorandum for the removal action for seeps $C$ and $D$ will be completed by February 18, 1994.

A meeting will be conducted to discuss the FS strategy for the entire WAG 5 site. A meeting on this topic with EPA and TDEC is planned for February or March 1994.

\subsubsection{ORNL WAG 6}

\section{Description}

ORNL WAG 6 consists of SWSA 6, the Emergency Waste Basin, and the Explosives Detonation Trench.

SWSA 6 is located northwest of WOC near White Oak Dam and State Highway 95. This 68-acre site is still in operation as a waste burial ground for solid low-level radioactive waste. Contaminants of concern include various radionuclides and hazardous chemicals.

The Emergency Waste Basin is located north of SWSA 6. It is a 2-acre basin constructed as an LLLW or process-waste holding basin for use when ORNL might be unable to release wastes to White Oak Creek. The basin has never been used, and no releases have been detected in the stream leaving the basin; however, surface contamination has been found in the basin.

The Explosives Detonation Trench is located in the northern part of SWSA 6. It was used to detonate explosives and shock-sensitive chemicals requiring disposal. Explosive wastes were laid in the bottom of the trench and detonated with a small plastic explosive charge. No releases are believed to have occurred.

\section{Accomplishments}

Comments were received from EPA and TDEC on the Environmental Monitoring Plan, and a response to the comments is being prepared. Initial field data collection activities associated with the Environmental Monitoring Program began.

The revised WAG 6 RCRA Closure Plan was submitted to TDEC and EPA for review.

Construction of the Tumulus I and II cap was initiated. 
The WAG 6 portion of the December 7, 1993, ER public information meeting was conducted. The WAG 6 presentations were attended by -125 people. The public was briefed on the revised WAG 6 strategy, which includes long-term monitoring with deferred remedial action until improved technologies are available for remediating the site in a cost-effective manner. Feedback on comments received during the meeting and in press reports indicates that the presentation was well received.

\section{Concerns}

Concern: The revised WAG 6 strategy needs to be documented in writing in order to meet the legal requirements of the FFA and other regulatory requirements. Impact: Failure to properly document the rc sed strategy could open up legal issues regarding the WAG 6 RCRA Closure Plan approved by TDEC in September 1988. Action: EPA, TDEC, and DOE need to agree on an appropriate vehicle for documenting the revised WAG 6 strategy.

\section{Scheduled Activities for Next Quarter}

Additional portions of the Environmental Monitoring Program will be initiated including surface water and groundwater sampling.

The installation of the additional characterization wells required by the Environmental Monitoring Program will begin, and well maintenance/repair of the existing monitoring wells will begin.

The Monitoring Station 1 and 3 construction contracts will be awarded in preparation for third quarter construction.

The final WAG 6 Environmental Monitoring Plan will be completed and issued for approval.

\subsubsection{ORNL WAG 7}

ORNL WAG 7 comprises 17 units: 7 LLLW seepage pits and trenches, the Homogeneous Reactor Experiment fuel wells, experimental hydrofracture injection areas and surface contamination, shielded transfer tanks, and a decontamination facility.

These units are located in the vicinity of SWSA 4 (in Melton Valley about 0.5 mile southwest of the main ORNL complex and bounded on the northern side by Lagoon Road). Several radioactive contaminants of concern have been identified to date.

\section{Accomplishments}

The driving of a rod into pit 1 to probe its bottom was completed. Preliminary in situ radioactivity assays have indicated that the depth of major radioactive contamination is at least $23 \mathrm{ft}$ below the present asphalt surface of the pit. Previously, it had been presumed that the pit's bottom was $-15 \mathrm{ft}$ below the present grade; it is now apparent that $\sim 10 \mathrm{ft}$ of clean fill was placed over the original land surface when the pit was capped with asphalt in 1980 . This greater-than-expected depth to radioactive contamination will probably necessitate scraping off the clean fill prior to in situ vitrification so that the complete depth of radioactive 
contamination can be treated. Sampling and characterization will be designed to support this scenario.

Work was initiated by Battelle Pacific Northwest Laboratory to design and fabricate an ISV off-gas hood and filtration system for this treatability study.

Comments were received and conditional approval obtained from TDEC and EPA, Region IV, on the ISV treatability study work plan (DOE/OR/1158\&D1); revisions will be incorporated next month in the final version of this work plan.

In situ logging of beta/gamma activities in six vertical pipes driven into ORNL seepage pit 1. was completed. A single layer of major radioactive contamination has been located 23-25 $\mathrm{ft}$ below the present asphalt cap over the pit. Moreover, the contamination falls off dramatically below this depth indicating that a single definitive depth target for in situ virification is applicable for pit 1 .

\section{Concems}

None.

\section{Scheduled Activities for Next Quarts}

The site safety and health and quality assurance plans for sampling pit soil and sludge will be completed.

The in situ radioactivity logs of rods driven in pit 1 will be completed.

The installation of driven perched water monitoring wells will be completed, and a perched water sampler will be obtained.

The soil and sludge sampling of pit 1 contents will be initiated.

The treatability study work plan for this project will be finalized.

The design of the ORNL ISV off-gas collection hood will be completed.

\subsection{ORNL WAG 10}

\section{Dewcription}

WAG 10 consists of the injection wells, observation wells, monitoring wells, and grout sheets associated with two hydrofracture process experimental sites: the Old Hydrofracture Facility (OHF) and the New Hydrofracture Facility. The above ground components at these sites are located within OUs 5,7 , and 8 .

Hydrofracture Experiment Site 1 is located within the boundary of WAG 7 (south of Lagoon Road) and was the first experimental site for the injection of grout (in October 1959) that took place as part of a testing program for observing the fracture pattern created in shale and for identifying potential operating problems. Water, tagged with ${ }^{137} \mathrm{Cs}$ and ${ }^{141} \mathrm{Ce}$, was 
injected in a grout mixture including diatomaceous earth and cement. No hazardous waste constituents or LLLW should have been present in the grout.

Hydrofracture Experiment Site 2 is located about 0.5 mile $(800 \mathrm{~m})$ south of the 7500 (experimental reactor) area (OU 8). The second hydrofracture experiment was designed to duplicate, in scale, an actual disposal operation. However, radioactive tracers were used instead of actual waste. Water tagged with ${ }^{137} \mathrm{C}$, cement, and bentonite was used in formulating the grout. No nonradioactive hazardous constituents should be contained in the grout.

The OHF is located 1.0 mile $(1.8 \mathrm{~km})$ southwest of the main ORNL complex, west of SWSA 5. The facility, commissioned in 1963, served as a pilot plant to demonstrate the feasibility of permanent disposal of liquid radioactive waste in impermeable shale formations by hydrofracture methods. Wastes used in the experiments included concentrated LLLW, ${ }^{90} \mathrm{Sr}$, ${ }^{137} \mathrm{Cs},{ }^{24} \mathrm{Cm}, \mathrm{TRU}$, and other unidentified radionuclides.

The New Hydrofracture Facility is located $900 \mathrm{ft}(300 \mathrm{~m})$ southwest of the OHF on the south side of Melton Branch. The facility was constructed to replace the OHF and serve as the operational LLLW waste disposal system for ORNL. Wastes used in the injections were concentrated LLLW and sludge removed from the gunite tanks, ${ }^{90} \mathrm{Sr},{ }^{137} \mathrm{Cs},{ }^{244} \mathrm{Cm}$, TRU, and other nuclides.

\section{Accomplishments}

The final WAG 10 OU 3 (Hydrofracture Wells and Boreholes) Waste Management Plan; Database Management Plan; and Environmental, Safety, and Health Plan were issued.

Wellhead tapping and sampling activities were initiated.

\section{Concerns}

None.

\section{Scheduled Activities for Next Quarter}

Wellhead tapping and sampling will continue.

The Health and Safety Plan associated with geophysical logging will be completed.

\section{ORNL WAG 11}

\section{Description}

ORNL WAG 11 is the White Wing Scrap Yard located at the west end of East Fork Ridge between State Highway 95 (White Wing Road) and the Oak Ridge Turnpike. The site, which covers -30 acres, was used to store contaminated materials from the three Oak Ridge plants. Wastes (equipment, tanks, and trucks) were stored above ground. Much of the stored

materials and contaminated soil was removed between 1966 and 1971; however, smaller quantities of contaminated debris (e.g., scrap metal and concrete) remain at the site. Contaminants of concern identified to date are ${ }^{137} \mathrm{Cs},{ }^{234} \mathrm{Th},{ }^{235} \mathrm{U}$, and PCBs. 
Accomplishments

On November 1, an Interim Record of Decision on the surface debris cleanup action was initiated. Cleared as of the end of December 1993 were 71 grids of a total of 114.

\section{Concerns}

None.

\section{Scheduled Activities for Next Quarter}

Interim remedial activities will be completed.

\subsubsection{ORNL WAG 13}

\section{Description}

ORNL WAG 13 consists of the Cesium-137 Contaminated Field and the Cesium-137 Erosion/Runoff Study Area. The contaminated field is located $-330 \mathrm{ft}$ north of the Clinch River at Clinch River Mile 20.5. The 50-acre area was set aside for studying the ecological effects of simulated fallout of ${ }^{137} \mathrm{Cs}$, which would occur in the event of a nuclear war. The contaminant consisted of ${ }^{137} \mathrm{Cs}$ fused at high temperature to silica particles. After -20 years (since contamination), about $5.2 \mathrm{Ci}$ of activity remains.

The Erosion/Runoff Study Area is located due north of the confluence of the White Oak Creek and the Clinch River. The purpose of this study area was to use the field contamination to study runoff, erosion, and infiltration of ${ }^{137} \mathrm{Cs}$ on a silt-loam soil.

\section{Accomplishments}

The removal of cesium from plots, an interim action, was completed on October 31.

Plots 2 and 4 at WAG 13 were backfilled with clean soil. The perimeters and side walls of Plots 6 and 7 are being excavated to remove the ${ }^{137} \mathrm{Cs}$ source. The job is in its final stages and should be completed in early January 1994.

\section{Concerns}

None.

\section{Scheduled Activities for Next Quarter}

A radiological survey of WAG 13 to document the interim cleanup of the plots will be conducted.

A postconstruction report will be submitted to the regulators for approval. 


\subsection{ORNL Groundwater OU/Well Pluging and Abandonment}

\section{Dearipion}

Groundwater Ilowpaths and restoration activities are not constrained by WAG boundaries. Therefore, groundwater activities acociated with individual WAG source OUs have been integrated over a larger geographic area. The groundwater OU consiating of Melton Valley and Bethel Valley has been eatablished and will be the focus of a multi-year, long-term investigation.

The ORNL Well Plugging and Abandonment Project was established for the purposes of developing, implementing, and managing the plugging and abandonment of unneeded wells and coreholes at ORNL with the exclusion of WAG 6 wells and certain unique hydrofracture wells (WAG 10). A field survey was begun for the purposes of inventorying ORNL wells/coreholes and verifying and updating the existing ORNL well database. In addition, an ORNL well plugging and abandonment plan was prepared that presents the strategy and detailed approach to be used for well/corehole decommissioning at ORNL.

\section{Accomplishments}

Work continued on the preparation of the RI Work Plan.

\section{Concerns}

None.

\section{Scheduled Activities for Next Quarter}

The draft RI Work Plan for the groundwater OU will be submitted to the regulators by the end of March 1994.

\subsection{OAK RIDGE K-25 SITE}

\subsubsection{K-770 OU}

\section{Description}

The K-770 OU includes a contaminated scrap metal yard and associated contaminated debris, two buildings used as part of a thermal diffusion plant in the 1940s, and a sewage treatment plant. The unit is located southwest of the main plant area near the Clinch River. Operation time frame for the various subunits ranged from 1943 to the early 1960 s. The scrap metal yard and sewage treatment plant are still in operation.

The K-770 Scrap Metal Yard contains $-20,000 \mathrm{ft}^{3}$ of asbestos-containing metal along with waste materials contaminated with uranium, transuranics, mercury, and asbestos. Building K-726, located within the K-770 Scrap Metal Yard, was used for storing PCBs. Suspected contaminants of concern in Buildings K-722 and K-725 are beryllium, mercury, asbestos, and uranium. In 1950, a transformer exploded at the K-709 switchyard, releasing 
PCB-contaminated oil in the area. Sewage that may contain traces of radioactive contaminants is present at the K-710 sewage treatment plant.

Accouplishments

Work began on resolving comments received from TDEC and EPA on the RI Work Plan for the K-770 OU.

Concerns

None.

\section{Schadulad Activite for Ner Quartor}

A revised RI Work Plan that addrewses comments received from EPA and TDEC will be completed and transmitted to the regulators.

\subsubsection{K-901 OU}

\section{Descripion}

The K-901 OU consists of a contaminated burial ground, landfarm, holding pond, and two construction waste disposal areas. The $O U$ is located northwest of the main plant.

K-1070-A Old Contaminated Burial Ground, northweat of Building K-33, was used for the disposal of several types of material from the 1940 to 1976 . The burial ground contains $-35,575 \mathrm{ft}^{3}$ of uranium-contaminated material and $2430 \mathrm{ft}^{3}$ of thorium-contaminated material. Other material includes $\mathrm{UF}_{6}$ cylinders, beryllium chips, boron, radioactive $\mathrm{NaF}$, oil, rags, etc. The K-1070-A landfarm received $-5000 \mathrm{ft}^{3}$ of fuller's earth between 1979 and 1985 . The fuller's earth was laden with concentrated acids, sludges, and other degradation products from uranium enrichment cascade oil.

The K-901-A Holding Pond received chromated, cooling-tower water blowdown and a variety of other wastes from barrels drained into the pond in the late 1950. The K-901 Waste Disposal Area and K-901-A Sanitary Disposal areas each received construction wastes beginning in the 1940 s. Small pockets of radioactive contamination have been found at the K-901-A Sanitary Disposal Area.

Accomplishments

A site visit was conducted on November 23. Project team members were briefed on each area of concern within the OU. The preliminary mobilization planning activities were discussed.

\section{Concerns}

Concem: Funding has been delayed. Impact: Delayed funding will result in delays in the start of mobilization efforts and field activities. The RI schedule and the ongoing Ecological Risk Assessment schedule will be directly impacted. Action: The schedule has been modified 
to reflect the delay in funding. (Note: Funding for FY 1994 activities was received after the end of the current reporting period.)

Schectuled Activities for Nert Quarter

None.

\section{$3.3 .3 \mathrm{~K}-1070$ OU}

\section{Description}

The K-1070 OU consists of the K-1070-C/D Classified Burial Ground, located on a hill at the eastern edge of the K-25 plant. The burial ground is comprised of three major disposal areas: large trenches, small pits, and three earthen dike areas. Both low-level radioactive and nonradioactive, nonhazardous waste materials and equipment were buried in the large trenches. The small pits were used for the disposal of hazardous liquid wastes and glass. The earthen dike areas were used for storing drums of hazardous waste. Contaminants of concern at the burial ground are volatile and semivolatile organics, uranium-contaminated scrap metal, uranium compounds, lead, and other metals. In addition, an interim corrective action is planned for the SW-31 leachate seep, which is located immediately west of the site and has been likely contaminated by the burial ground.

\section{Accomplishments}

Preliminary field activities were completed, and a meeting was held with EPA and TDEC officials to discuss additional sampling activities needed for the K-1070 C/D Classified Burial Ground. The preliminary results from K-1070 C/D RI field activities, the installation of three additional groundwater monitoring wells, and potential soil sampling inside two pits were discussed.

\section{Concerns}

None.

\section{Scheduled Activities for Next Quarter}

Field activities for the implementation of the RI Work Plan will be completed.

Work will begin on the RI Report and FS.

\subsubsection{K-1070 SW-31 Spring Project}

\section{Description}

This project will implement an interim remedial action for the K-1070 Leachate seep (SW-31) to reduce risk to human health and the environment and to achieve compliance with pending regulations. The seep appeared after an attempted reclamation of the area bordering the west end of the K-1070-C/D Classified Burial Ground, which was swampy and had an unpleasant smell. The K-1070-C/D Classified Burial Ground was used to dispose of a variety of equipment and waste, including solvents and hazardous chemicals. The seep currently flows 
into a storm drain that discharges into Mitchell Branch. The preferred remedial action involves air stripping the discharged water to remove volatile contaminants after pretreatment to remove iron, followed by carbon filtration (polishing) to remove PCBs. The effluent, after acceptance criteria are met, would be diverted to the Central Neutralization Facility for final treatment and discharge in compliance with the facility's NPDES permit.

Accomplishments

The Phase II Remedial Design Report was submitted to TDEC and EPA on November 22.

Concerns

None.

\section{Scheduled Activities for the Neat Quarter}

Flow collection, transport, and treatment activities at the SW-31 Spring will be initiated on January 13, 1994, in accordance with the Phase I Remedial Action Work Plan.

\subsubsection{K-1407 OU}

\section{Description}

The K-1407 OU contains seven solid waste management units (SWMUs): the K-1407-A Neutralization Pit, the K-1407-B Holding Pond, the K-1407-C Retention Basin, K-1407-C and K-1417 Soil, the K-1070-B Old Classified Burial Ground, the K-1700 Stream (Mitchell Branch), and the K-1202 Hazardous Waste Storage Tanks. The K-1407 OU is located east of the K-25 building at the northern edge of the K-25 Site.

The K-1407-A Neutralization Pit is a 33,000-gal reaction pit where sulfuric acid and calcium hydroxide are added to neutralize corrosive waste streams. The neutralization pit has processed various cleaning solutions and has received heavy metals.

The K-1407-B Holding Pond received neutralized cleaning solutions from the cleaning of nickel-plated steel pipes. The pond also received a variety of organic and radioactive wastes from other sources. The K-1407-C Retention Basin was used for storing sludges from the $B$ pond. Both ponds are RCRA Interim Status Units and are awaiting closure. Since sludge removal during 1987 and 1988 , radionuclides are the only remaining contaminants.

$\mathrm{K}-1407-\mathrm{C}$ and $\mathrm{K}-1417$ Soil is located north of the $\mathrm{K}-1407-\mathrm{C}$ pond. Uranium is the only suspected contaminant in this soil.

Buried at the K-1070-B Old Classified Burial Ground is a collection of materials, equipment, and scrap taken from the S-50 thermal diffusion plant, K-1131 feed plant, and K-25/K-27/K-29 diffusion buildings. Contaminants include lead, uranium, and other metals.

The K-1700 Stream (Mitchell Branch) has received wastes from a variety of sources, including the K-1407-B pond and several area underground storm drain systems. 
The K-1202 Hazardous Waste Storage Tanks consist of two elevated storage tanks of 15,000 gal capacity each. The tanks originally contained processing equipment lubricating oils, but in recent years the tanks have been used for the interim storage of mixed wastes.

For each unit, an RI/FS Report, a Proposed Plan, and a ROD will be prepared. The constituents not addressed in the formal RCRA process will be addressed in the CERCLA process. This will meet the need to address the radionuclide contamination. The above actions will achieve complete remediation of the $\mathrm{K}-1407-B$ and $\mathrm{K}-1407-\mathrm{C}$ units as CERCLA source OUs and as RCRA Interim Status Units. Because the CERCLA actions at both the K-1407-B and K-1407-C units will be the same, one set of CERCLA documents will be produced that will address both units.

\section{Accomplishments}

Approval was received from TDEC and E?A on the ROD for the K-1407-B Holding Pond and K-1407-C Retention Basin.

The Remedial Design Report for the K-1407-B and -C ponds was submitted to TDEC and EPA on October 11.

The Remedial Design/Remedial Action Work Plan for the K-1407-B and -C ponds was submitted to TDEC and EPA on October 5.

\section{Concerns}

Concerm: If the K-1407 Ponds area is indeed a wetlands, then an Environmental Assessment may be required to assess potential NEPA impacts at the site. Impact: The time required for the preparation and approval of an Environmental Assessment could delay the remedial action. Action: A wetlands determination needs to be completed and a decision made regarding additional NEPA requirements.

\section{Scheduled Activities for Next Quarter}

The Remedial Design Report (D2 version) will be submitted to EPA and TDEC.

\subsubsection{Pond Wate Management Project}

\section{Description}

The K-141? Drum Storage Yard is a RCRA-permitted waste storage area. There were $-67,000$ drums stored on the yard and $-10,000$ drums stored in the K-25 vaults containing sludge from the K-1407-B Holding Pond and the K-1407-C Retention Basin. The sludge contains inorganic, organic, and radioactive contamination and was removed from the ponds during RCRA closure activities in 1988. Prior to storage at K-1417, the sludge was either drummed or stabilized in a concrete grout mixture at the K-1419 Sludge Fixation Facility. 
Accomplishments

A Part B Permit Modification that would allow raw sludge to be stored in the K-1065 facilities was submitted to TDEC for approval. Temporary authorization was received from TDEC to store raw sludge in K-1065.

The repackaging of raw sludge waste in 21st Century containers continued.

Work began on developing procurement strategies for an outside vendor to handle raw sludge treatment and disposal activities.

A tour was conducted for TDEC representatives of the Pond Waste Management Area and the K-1065 waste storage facilities.

Phases I and II of demobilization efforts on the K-1417 pads were completed.

The design of the pole mounted transformers that will replace the 1,000 KVA substation now on loan from the Y-12 Plant was completed. The transformers have been obtained and will undergo verification checking.

Concerns

None.

Scheduled Activities for Next Quarter

Demobilization activities on the K-1417 pad will be completed.

Repackaging of raw sludge in 21st Century containers will continue.

Work will begin on revising the Action Plan after the regulators have approved the scope of work.

\subsubsection{K-1414 Bioremediation (Underground Storage Tank Earty Action)}

\section{Description}

The purpose of the K-1414 UST Site reassessment is to determine the magnitude and extent of diesel contamination in the soil and groundwater at the K-1414 UST Site. Diesel fuel has leaked from a 9000-gal tank, located in the main plant area, north of the K-1414 garage. The tank has been removed, free liquid collected, and the excavation backfilled.

Accomplistments

The final Environmental Reassessment Work Plan and Corrective Action Plan were submitted to TDEC for review and approval.

\section{Concerns}

None. 
Schedule Activitios for Next Quarter

Free product removal activities will continue and comments on the Corrective Action Plan will be resolved.

\subsection{CLNCH RIVER}

\subsubsection{Clinch River OU}

\section{Description}

The Clinch River RI focuses on the portions of the Clinch and Tennessee rivers that may have been adversely affected by contaminants released from the mid-1940s to the present from the DOE ORR. The Melton Hill Reservoir and the Clinch River, downstream from Melton Hill Dam, form the southern and eastern boundaries of the ORR. The Clinch River enters the Tennessee River system of multipurpose impoundments near Kingston, Tennessee, $34 \mathrm{~km}$ downstream from the Oak Ridge complex. This WAG/OU/study area includes Melton Hill Reservoir and the Clinch River from Melton Hill Dam to Kingston.

The contaminants released from the ORR originate from research, industrial, and waste disposal activities conducted at ORNL, the Y-12 Plant, and the K-25 Site. The contaminants released from these facilities include a variety of radionuclides, metals, and organic compounds. Some liquid wastes are discharged to streams on the ORR, which drain into the Clinch River; however, much of the waterborne contamination is derived from seepage into the shallow groundwater from old waste storage pits and trenches. The contaminants of concern in the river/reservoir system were determined by preliminary human health risk screening using a variety of exposure pathways and nonconservative screening. PCBs were identified as contaminants of concern through fish ingestion. TDEC has a fish consumption advisory in effect for Melton Hill Reservoir and the Clinch River arm of Watts Bar Reservoir. Arsenic, chromium, mercury, selenium, zinc, ${ }^{137} \mathrm{Cs}$, and ${ }^{60} \mathrm{Co}$ constitute a risk only if deepchannel sediments are dredged and dredged spoils are placed on land.

\section{Accomplishments}

Verbal approval was received from TDEC and EPA, Region IV, on dividing the Clinch River-Watts Bar Reservoir OU into two OUs and proceeding with an accelerated RI/FS and ROD for the new Lower Watts Bar Reservoir OU. No additional sampling will be required in Lower Watts Bar Reservoir, and the RI baseline risk assessment will be based on historical and Phase 1 data.

A trial date of May 16, 1994, was received for the Watts Bar Resort Owners' lawsuit against Martin Marietta Energy Systems, Inc., and Union Carbide, Inc. A motion for summary dismissal has been filed, stating that the Resort Owners have not demonstrated a loss of livelihood or property values as a result of contaminants released to Watts Bar Reservoir from activities on the DOE ORR. The judge for the trial has requested that both the plaintiffs and the defense submit a list of individuals who are expected to be called as expert witnesses at the trial. 
A workshop was held with Tennessee Valley Authority, Pacific Northwest Laboratory, University of Iowa, and Clinch River ER staff on modeling water, sediment, and contaminant flow in the Clinch River-Watts Bar Reservoir system. Three models are being used by this team to place bounds on the distribution of contaminants under several future scenarios. The information obtained as a result of this task will be used in site characterization activities, the risk and exposure assessment, and FSs.

Sediment samples were collected from the Tennessee and Clinch River arms of the Watts Bar Reservoir, and water samples were collected from the Clinch River arm of the reservoir for use in Phase 2 work on the Clinch River RI. Sediment samples were processed to yield both bulk sediment and sediment pore water fractions. Water and sediment will be submitted to independent laboratories for radiologic, organic, inorganic, and mercury speciation analyses.

Water samples were collected from the Clinch River arm of the Watts Bar Reservoir for use in Phase 2 work on the Clinch River RI. Samples including quality assurance/quality control samples were processed and will be submitted to the subcontracted laboratories for radiologic, organic, inorganic, and mercury speciation analyses.

Water toxicity tests with fathead minnows and Ceriodaphnia were completed for six sites on Poplar Creek and three sites on the Clinch River.

Sediment samples were collected for sediment toxicity testing as specified under task S3 of the Phase 2 Sampling and Analysis Plan for the Clinch River RI. Toxicity tests on bulk sediment will be conducted on Daphnia magna, hyalella azteca, and Microtox. Sediment porewater will be used for conducting toxicity tests on Ceriodaphnia dubia and Microtox.

Water and sediment samples were collected from Poplar Creek and the Clinch River for toxicity testing.

A meeting was held with ER Risk Assessment staff to discuss the integration of risk assessment software with the comprehensive database developed by Clinch River and WAG 6 database management staff.

Staff involved with the K-25 Groundwater OU were briefed on Clinch River ER Program activities. Interfaces between the Clinch River site characterization task and K-25 groundwater monitoring activities were discussed.

A tour of the sediment retention dam at WOCE was conducted for Richard Piltz, a congressional staff member from the Space, Science, and Technology Committee. Mr. Piltz visited the Environmental Sciences Division to become familiar with water resource issues in the ER Program.

Took -80 samples over a period of 3 days to accomplish sediment polygon map confirmation (sediment sampling task S1B).

Held a DQO meeting with EPA and TDEC staff to discuss the proposal for the RI/FS Report on the Lower Watts Bar Reservoir. 


\section{Concerns}

None.

Scheduled Activities for Next Quarter

Phase 2 sampling and analysis will continue. The FS for Lower Watts Bar Reservoir will be initiated.

\subsection{Lover Watts Bar Reservoir OU}

Deecription

The Watts Bar Reservoir is the first Tennessee River impoundment located downstream of the ORR. Tennessee Valley Authority's Watts Bar Dam, completed in 1942, is situated at Tennessee River kilometer 853.6 (river mile 530.5). The reservoir receives inflow from both the Tennessee and Clinch rivers. This WAG/OU/study area consists of that portion of the reservoir that extends from TRK 913.1 (river mile 567.5-mouth of the Clinch River at Kingston) to the Watts Bar Dam.

The source of ORR contaminants at this OU is the Clinch River. Because the dam was completed prior to the start of operations at ORR and also because the reservoir acts as an efficient trap for sediments and any associated particle-reactive contaminants, much of these contaminants have accumulated in the bottom of Watts Bar Reservoir over the years. The contaminants of concern and exposure pathways are the same as those for the Clinch River OU, with PCBs in fish posing the greatest health risk. TDEC has issued a fish consumption advisory for Watts Bar Reservoir. A fish consumption advisory is also in effect for the Fort Loudon and Tellico reservoirs, which are located upstream of the Watts Bar Reservoir and the ORR. Sediment contaminant concentrations, because of dilution by the Tennessee River and the greater spatial extent of the reservoir as compared to the Clinch River, are generally lower in Watts Bar Reservoir than in the Clinch River. Screening-level human health risk analyses indicate that contaminants in sediment pose a health risi only if deep channel sediments are dredged and the dredged spoil is placed on land.

Accomplishments

Accomplishments reported for the Clinch River OU apply also to the Lower Watts Bar Reservoir OU. Please see the Accomplishments reported on the previous two pages of this report for the Clinch River OU for a discussion of Lower Watts Bar Reservoir Accomplishments.

\section{Concerns}

None.

\section{Schedules Activities for Next Quarter}

Phase 2 sampling and analysis will continue. 


\section{OAK RIDGE ASSOCIATED UNIVERSTIIES (ORAU)}

\subsubsection{South Campus Facility OU}

Description

The South Campus Facility (SCF) OU is located within the city limits of Oak Ridge, Tennessee. It is bounded by Bethel Valley Road to the north, State Highway 62 to the east, Haw Ridge and the Clinch River to the south, and the western sectiou of Bethel Valley to the west.

A research facility operated by ORAU, SCF was originally established in 1945 to study the accidental irradiation of cattle that occurred during the testing of the first atomic bomb near Alamogordo, New Mexico. The scope of research soon included studies on the introduction and migration of radioisotopes in the food chain as well as various other agricultural problems.

The boundaries of SCF encompass -25 buildings and 130 acres of pasture land, but there is no enclosing fence. Access to the SCF property is generally unrestricted. Although several signs are posted to limit access, no fences or barriers exist to preclude access.

No documented evidence is available as to waste composition or quantity that may have been released to the environment at this location. Limited data exist, however, that identify potential hazardous waste sources and pathways. In addition, previous analytical data and the results of an inspection at this site indicate the presence of target compound list organics in the groundwater.

An RI at SCF was initiated in FY 1993. SCF areas included in the RI are the wastewater treatment plant, ponds, various laboratories, and animal containment facilities. Contaminants of concern include radionuclides, volatile organics, and pentachlorophenols.

\section{Accomplishments}

EPA and TDEC were briefed in November on the results of the RI. It was agreed at the meeting to combine the RI and FS documents into a single RIFS Report that will be due in September 1994.

DOE selected a new contractor, Jacobs Engineering, to prepare integrated decision documents to support the Oak Ridge FFA. Jacobs assumed full responsibility for preparation of the RI/FS Report on December 20; they have completed transition briefings with the previous contractor.

\section{Concerns}

None.

\section{Scheduled Activities for Next Quarter}

Work will continue on the RI/FS Report. 


\subsubsection{Froels Bend Area OU}

\section{Description}

The Freels Bend Area was used to support research conducted at the ORAU SCF. This area is located southwest of the SCF and is bounded on three sides by the Clinch River. Control herds of some animals were maintained on pasture land here with ancillary barns and outbuildings. The research facilities included the Low Dose Rate Irradiation Facility (LDRIF) and the Variable Dose Rate Irradiation Facility (VDRIF). Each of these facilities was used to expose and irradiate test animals that were subsequently observed over a period of time for exposure effects. The sources were removed from the LDRIF; however, six sealed ${ }^{60} \mathrm{Co}$ sources still remain stored at the VDRIF.

There are three reported disposal areas for animal carcasses and miscellaneous wastes in the Freels Bend Area. These areas have been termed Animal Burial Sites I, II, and III. Access to the $\mathbf{7 0}$ acres of the Freels Bend Area is restricted and not open to the general public, although the area is not fenced. The entrance to the access road is blocked with a locked bar gate.

Freels Bend Area regions to be investigated include those associated with the irradiation facilities, animal burial locations, and three small impoundments used in the care of control herds maintained at the Freels Bend Area. Contaminants of concern include radionuclides, organics, and metals.

\section{Accomplishments}

EPA and TDEC were briefed in November on the results of the site inspection. The results indicate that documentation supporting no further investigation can most likely be prepared, although it was recommended that additional background data be gathered to determine if elevated levels of beryllium and manganese exist for this site. There was also agreement on completing a maintenance action on the source wells at VDRIF.

On December 20, Jacobs Engineering assumed responsibility for the preparation of any required decision documents to support work at Freels Bend.

\section{Concerns}

None.

\section{Scheduled Activities for Nex Quarter}

Activities will be initiated to gather the additional background data required to support a no further investigation decision. 


\subsection{TECHNICAL OVERSIGHT AND TECHNICAL PROGRAMS}

\subsubsection{Background Soll Characterization Project}

\section{Description}

The main objective of the Background Soil Characterization Project (BSCP) is to provide comprehensive, reservation-wide background soil concentration data on significant potential contaminants of concern [organics, inorganics (metals), and radionuclides] in natural soils on the ORR. The BSCP addresses variability of analyte concentrations in terms of the dominant soil types that occur in the different geologic formations on the reservation, soil sampling horizons, and natural variations in soils. Other project objectives include providing baseline data for contaminated site assessments and estimates of human health risks associated with background levels of potentially hazardous constituents in soils on the ORR.

\section{Accomplishments}

All BSCP milestones and deliverables were completed on schedule.

\section{Concerns}

None.

\section{Scheduled Activities for Next Quarter}

BSCP records management activities will be completed, storage requirements determined, and the project closed out.

\subsubsection{Oak Ridge Environmental Information System}

\section{Description}

The Oak Ridge Environmental Information System (OREIS) is mandated by DOE-ORO to fulfill the environmental data base requirements established by both the FFA and Tennessee Oversight Agreement (TOA). At the direction of DOE-ORO, OREIS is being developed as a consolidated data base for environmental measurements for all facilities managed by Energy Systems. These facilities include ORNL, the Y-12 Plant, and the K-25 Site located in Oak Ridge and the gaseous diffusion plants located at Paducah, Kentucky, and Portsmouth, Ohio. The environmental data include data generated pursuant to the FFA and data generated under federal and state environmental permits. All data used in compiling regulatory reports will be included in OREIS.

\section{Accomplishments}

The recent stage of OREIS development has been focused on initializing the system for user evaluation in the winter and spring of 1994 and fully supported operations later in FY 1994. To support this status, the following two documents were issued for review and comment:

- An OREIS data management plan, version 2.0 (ES/ER/TM-39/R1) 
- An annual summary of the OREIS data base contents

Data from portions of ER reports were loaded into the data base. Records documenting the quality assurance review of the data were established.

The computer programs that provide the integration of the data analysis tools and user interface with the data base for OREIS version 2.0 were tested, and the testing was documented.

A meeting was held with TDEC Oversight staff to demonstrate specific data analysis scenarios. EPA Region IV offices were visited for the purpose of discussing the data base and systems development issues that are similar between the DOE and EPA organizations. The OREIS user interface was demonstrated on systems in Atlanta via internet communications.

OU maps for the latest revision of the ORR Site Management Plan for the ER Program were finalized. These maps contribute to the formal documentation of the OUs and will be available to the regulators and the public.

\section{Concerns}

Concern: Data generated by the site ER Programs are often deficient in several basic data management principles, making it extremely difficult to incorporate such data into OREIS in a timely manner. Impact: The loading of ER project data into OREIS is being delayed, thereby affecting the ability to provide data to the regulators on schedule. Action: DOE has directed Energy Systems to establish a data management program that will define a data management policy, process definition, and procedures to be executed for all ER projects. The roles and responsibilities of the ER projects, site programs, and OREIS data management will be clearly defined. Consistency in data management activities throughout the ER Program will be accomplished through regular reviews by this central data management program. The operational effectiveness of OREIS will be significantly enhanced when the data management program is fully implemented.

Concern: DOE-HQ conducted a "management review" of OREIS. The report from the review recommends significant changes and additions from the current course for OREIS development. Impact: Changes in the course of OREIS development will delay the attainment of full OREIS operations. Responding to analyses of OREIS development also impacts the management resources available for near-term supervision of the program. Action: Presentations were made to DOE-ORO and DOE-HQ to clarify the status and scope of OREIS development and to document the impact of the headquarters recommendations on OREIS operations and development. Actions with less impact on OREIS development have been defined to address the headquarters recommendations.

\section{Scheduled Activities for Next Quarter}

Appropriate data associated with reports identified in Appendix E of the FFA and due January-March 1994 will be provided.

The survey of current user practices and requirements (functional and data base) related to OREIS will be validated. 
Training will begin for OREIS users 20 that the evaluation of the system can begin.

The OREIS user's guide will be updated.

Version 2.0 of OREIS will be installed on ER site workstations.

OREIS-compatible computing resources will be provided to TDEC.

OREIS user and system owners groups will be formed.

An annual summary of OREIS products and of services provided by OREIS operations will be prepared.

\subsection{Aerial Remote Sencing Surveys}

\section{Description}

Remote sensing technologies provide efficient means for acquiring data for site characterization, change detection, and identification of potential areas of previous waste activities and acquiring updated information to support geographic data bases (e.g., facility data, land cover, and topography). The objectives of the Remote Sensing and Special Surveya Program (Aerial Remote Sensing Surveys) are to promote and manage routine examinations of the ORR and associated off-site areas and to provide screening-level site characterization data and aerial photography to the ER site programs. The program is dedicated to providing an experienced team of individuals to DOE and other federal agencies to demonstrate and test emerging remote sensing characterization technologies and technologies being transferred from other industries that may prove to be useful tools in environmental restoration and waste management characterization activities.

\section{Accomplishments}

The report Strategic Plan for the Utilization of Remote Sensing Technologies in the Oak Ridge Environmental Restoration Program was issued. The report outlines state-of-the-art remote sensing and geophysical technologies and describes the ability to apply these technologies for the purpose of managing routine and remotely sensed examinations of the ORR, the Portsmouth Gaseous Diffusion Plant, and the Paducah Gaseous Diffusion Plant.

A meeting was held to discuss the large magnetic and electromagnetic anomalies that were observed at the west end of Roger's Quarry. It was determined that the anomalies correlated with the expected locations of metals that were deposited at the site. The aerial data provide encouragement for the pursuit of magnetic and electromagnetic measurements on the surface of the quarry as remediation efforts continue.

Representatives of DOE and various federal agencies involved in SERDP met in Oak Ridge on December 15. A brief history of the operation and remediation of each study site was presented. Data processing capabilities were demonstrated from existing WAG 6 imagery. A status report on the ground truth data acquisition, which includes the collection of ground photos and video, model airplane photographs, oblique photographs, soil moisture samples, and meteorological data, was given. The results of a study of the historical imagerj of WAG 4 were presented. The ongoing acquisition of National Technical Means data was also discussed. 
As part of the SERDP Waste Site Study ground truth collection project, aerial photographs were collected on chowen investigation areas. Initial low-altitude (800-ft) natural color photographs were collected for portions of the Bear Creek OU 1 and for the Filled Coal Ash Pond. Low-altitude aerial photographs were aleo acquired for the seep areas of WAG 6 and Bear Creek OU 1.

Initial and second-phase collections of soil moisture data, ground-baeed photographs, and ground-based videos of chosen investigation areas were accomplished. A complete set of base aerial photographs of the study sites is being prepared to aid in the documentation of ground photographs and coil sample locations.

A meeting was held with John DiBenedetto of EG\&G Energy Meaurements, Inc., Santa Barbara Operations, to discuss the aerial testing phase of the laser-based remote fluorescence imaging system. During this phase, the system will be used to attempt to identify vegetative stress as well as uranium contamination.

Les Beard (Energy Systems) and Louise Pellerin (USGS) agreed on a joint effort designed to aid in the interpretation of the Phase II ORR data. A rapid filtering approach will be used to pull out characteristic responses of specific targets. The filters will be built with both synthetic 3-D models and from characteristic profiles in the field data.

D. M. Carden (DOE/ORO) and R. C. Durfee (Energy Systems) made a presentation on the Remote Sensing and Special Surveys Program to the Acrial Measurements System Working Group at the Remote Sensing Laboratory, Las Vegas, Nevada (on October 5 and 6).

D. M. Carden presented the results of the 1992 Aerial Radiological Survey of the ORR to the Environmental Quality Assessment Board.

ChemRad Tennessee Corporation conducted a ground-based geophysical survey of the Scarboro Road karst site. The survey was performed in support of helicopter geophysical activities.

The threatened and endangered plant species surveys of some compartment areas, the Melton Valley Groundwater OU, Bear Creek OU 4, and the Bear Creek OU were completed. The compartment areas are being surveyed to determine the potential impacts on rare plants and wetlands due to the removal of pine trees. The pine trees are being removed to try to control the pine beetle infestation. All of the OUs located on the ORR have been recently surveyed for state and federal listed threatened and endangered plant species.

Maps received from Geonex Aerodat were reviewed to identify any and all electrical, magnetic, and radiometric structures and anomalies that may be present on the ORR. The review of these maps allowed the identification of several anomalous sites on the ORR. An inspection of these sites was conducted.

A better digital elevation model of the Melton Valley/WAG 6 area was generated from contour data using the Triangulated Irregular Network methodology. This has allowed for more precise 3-D surface modeling of the Melton Valley area. 


\section{Concense}

None.

Schatulad Activites for Nat Quarter

Members of EG\&G Energy Measurements, Inc., will visit the ORR to further discuss the aerial teating phase of the laser-based remote fluorescence imaging system and the Daedalus scanner survey schedule.

Work will begin on the high recolution data acquisition portion of the airborne geophyaical survey of the ORR.

The annual report on activities of the Remote Sensing and Special Surveys Program will be issued.

\subsubsection{Riuk Amewment Program}

\section{Description}

A risk assessment, as defined in the DOE-ORO Interim Policy Guidance on Environmental Restoration Risk Assessment Initiation, Implementation, and Interaction, is the process of identifying, defining, and characterizing the adverse consequences of exposure to hazardous and radioactive materials. Under the ER Division, risk assessment includes a baseline risk asseasment, refinement of preliminary remediation goals, and risk evaluation of remedial alternatives. Risk assessment may have both a human health risk ascessment component and an environmental risk assessment component where the human health risk assessment identifies, analyzes, and characterizes adverse health effects in human receptors and an environmental risk assessment identifies, analyzes, and characterizes adverse impacts on other environmental receptors (i.e., local flora and fauna, etc.).

The Risk Aseessment Council was established to ensure consistent implementation of established methodology and technical defensibility of all risk assessments produced as part of the remedial activities on the ORR and for the other DOE-ORO facilities, Paducah and Portsmouth. The Risk Assessment Council is a multidisciplinary team of site risk assessment team leaders and other Energy Systems personnel with expertise in the following areas: human health risk, ecological risk, toxicology information and data bases, risk model validation, sensitivity/uncertainty analyses, and risk assessment project implementation. As outlined in the DOE-ORO interim policy guidance, the Risk Assessment Council is responsible for the following:

- providing advice and guidance on appropriate risk assessment methodology and procedures;

- developing appropriate methods, procedures, models, and/or data needed to fulfill risk assessment needs of the site programs; 
- providing appropriate review of site programs' risk assessment implementation to ensure consistent application and interpretation of risk ascessment guidance and methodology; and

- supporting ER Division risk assessment needs through the research and development of critical risk ascesument data gaps.

Acocomplistuments

A meeting was held with TDEC to discuss the EPA's draft soils screening level guidance released in September 1993. The focus of the meeting was the derivation of soil remediation goals for Tennessee and the identification of how various groups would be affected by these goals. At the meeting, it was made clear that the option of doing a complete risk asseasment will be left in legislation even if tables of soil remediation screening goals are promulgated.

A meeting was attended with EPA in Atlanta to discuss comments on the EFPC RI Report. The focus of the meeting was on major issues including risk assessment (human and ecological) assumptions and methodology. Consensus was reached regarding how to handle these issues with actions to be taken by all in follow-up discussions.

Fate and transport, risk assessment, and FS risk reduction information was submitted for future inclusion in the Gunite and Associated Tanks OU RI/FS report.

The results of the baseline risk assessment conducted on the Abandoned Nitric Acid Pipeline (Upper EFPC OU 2) were presented to EPA IV and TDEC in Oak Ridge on October 20. There was general agreement that the risk assessment approach employed was supportive of the project, and it was agreed that Y-12 ER would submit the Site Characterization Summary and the Proposed Plan to the regulators for review.

The Baseline Risk Evaluation was completed on the Y-12 Alpha-4 building. This was the first Baseline Risk Evaluation completed for a D\&D facility.

The evaluation of Chestnut Ridge OU 2 (Filled Coal Ash Pond/Upper Branch) Phase I and II data was completed. Information gained from this evaluation will be used in the Risk Assessment, which is proceeding on schedule.

Freels Bend characterization information was screened against PRGs in preparation for a presentation of findings to EPA and TDEC.

\section{Concervs}

Concern: A risk assessment strategy for dealing with key issues on the ORR has not been agreed on by all parties to the FFA. Impact: The inconsistent approach to addressing these issues could result in significant loss of time and increased cost. Action: A document that can serve as a baseline for discussion is being prepared for use at a risk assessment meeting of all FFA parties in February. At this meeting, concurrence on the strategy outlined in this document will be reached, or the document will be revised to reflect necessary changes agreed on at the meeting. 
Schedulad Activities for Next Quarter

A meeting with TDEC and U.S. EPA, Region IV, will take place for the purpose of discusaing the proposed risk assessment strategy for the ORR. The result of the meeting will be the submittal of a document that defines an agreed-upon risk assessment strategy for the ORR.

Four new toxicity profiles for contaminants of concern will be submitted.

Toxicity values will be updated and submitted to the Risk Assessment Council for distribution to appropriate parties.

A techrical memorandum on the role of risk assessment in the alternatives evaluation will be submitted.

\subsection{Foderal Facility Agreement and Tennewee Overright Agreement}

\section{Description}

Section 120 of CERCLA requires federal facilities listed on the National Priorities List to enter into an FFA with EPA. The ORR was added to the National Priorities List in the fall of 1990. Subsequently DOE, EPA, and TDEC entered into this agreement. The primary purpose of the FFA is to establish a procedural framework and schedule for investigating and remediating contaminant releases at a site (the ORR) that pose a threat to human health and the environment.

The TOA obligates Tennessee to pursue a "program of independent monitoring and oversight," primarily related to DOE compliance with environmental laws, DOE radiation protection programs, and joint Tennessee-DOE emergency preparedness and response activities. The TOA obligates DOE to provide technical and financial support for Tennessee's oversight of and participation in the FFA, in addition to establishing and maintaining complaint programs.

\section{Accomplishments}

The Oak Ridge Reservation Site Management Plan for the Environmental Restrration Program was completed and submitted to EPA and TDEC for review and approval.

The DOE-proposed FY 1994 Appendix E milestones and the ORR FY 1995 and FY 1996 prioritized work activities were submitted to TDEC and EPA for their review during November.

A meeting of FFA project managers (DOE, EPA, and TDEC) was held on December 6. Discussions focused on providing training for the DQO scoping workshops for the OU task teams, FY 1994 FFA Appendix E milestones, the risk assessment strategy for the reservation, and FFA Appendix $C$. The need for an additional operating instruction that would deal with OU scheduling logic was identified.

FFA project managers met on December 9 with ER Progran managers to negotiate the FY 1995 and FY 1996 prioritized work activities. The results of the meeting were 
inconclusive, and EPA will rework their proposed work activities for the reservation and submit these to DOE and TDEC for their review and later renegotiation efforts.

Agreement was reached with TDEC and DOE D\&D Program managers on future actions required for compliance with the intent of the TOA.

Concerns

None.

Schectuled Activities for Nert Quarter

The FFA Appendix $C$ update will be reworked to include an additional phase of work for identifying all areas of concern under the operational programs and the D\&D Program that should be considered for future remedial action by ER.

The FY 1994 Appendix E will be reworked for approval by the three FFA parties.

Approval will be obtained on the operating instruction dealing with the FFA OU scheduling logic. All FFA operating instructions will be proposed for inclusion in a new FFA appendix to ensure their implementation. 


\section{RESPONSE ACTION CONTRACTOR ASSIGNMENTS}

Each FFA quarterly report includes a listing of the identity and assigned tasks of each of the DOE contractors performing work under the FFA The primary contractorsMK-Ferguson, Jacobs Engineering, EBASCO, and Energy Systems-will be performing work at all locations within the ORR. The following is included to satisfy this requirement.

\subsection{OAK RIDGE Y-12 PLANT}

Camp, Dresser, and McKeo-Development of an RI Work Plan for Chestnut Ridge OU 1. Development of an RI Report for Chestnut Ridge OU 2.

CH2M Hill-Provision of comments on previous RI plans for the Filled Coal Ash Pond. [Closed]

Colorado State University-Consulting concerning the DNAPLs in the Bear Creek Burial Ground. [Closed]

The Earth Technology Corporation-Development of the RI plan and RI of the S-2, Coal Pile Trench, Salvage Yard, and Building 81-10 sites. Subcontractors include Singleton Labs and A. L. Clark for drilling, IT Copporation for analytical support, HER Technical for data management and health and safety support, and Intemational Waste Management Syutems for engineering support. [Closed]

ETE Consulting Engineering Inc-Provision of professional services.

Geraghty \& Miller, Inc-Support in preparation of all postclosure permit applications and preparation of Bear Creek Valley OU 4 RI plan.

Highland Drilling Company-Characterization well drilling.

IT Corporation-Sampling and analysis.

Jacobs Engineering-Preparation of integrated RCRAVCERCLANNEPA decision documents, including FSs, Proposed Plans, RODs, Environmental Assessments, EISs, documents for interim actions, and cost estimates associated with these documents. Provision of technical support for RIs, assessments and investigations for off-site locations, remedial action verification, DOE and Energy Systems community relations activities, requirements associated with the Administrative Record, and risk assessments.

SAIC-Field sampling at Bear Creek Valley OUs 2 and 4, development of an RI Report for Bear Creek Valley OU 2, fieldwork for Upper EFPC OU 2 RI, data management support, support for ER strategic plan development and field mobilization, and assistance to on-site laboratories with the implementation of Contract Laboratory Protocol reporting.

SONSUB-Underwater surveying of Rogers Quarry. There is a separate subcontract for the closure of Kerr Hollow Quarry.

Univerxity of Kansas-Support for geophysical studies concerning DNAPL migration. [Closed]

Univertity of Tennesce-Hydrogeological support. 
University of Waterioo-Consulting concerning the DNAPLs in the Bear Creek Burial Ground and PCB experiments.

\section{OAK RIDGE NATIONAL LABORATORY}

Advanced Sciences, Inc (AST)-Administrative support, field coordination, and technical integration.

Analyan-Administrative support.

Automated Sciences Group-Biological data analysis, support for management, analysis, and interpretation of biological data from laboratory and field studies.

Battelle Pacilic Northweat Laboratory-Design and fabrication services for an ISV off-gas hood and filtration system.

Bechtel National, Inc (Team members aleo include CH2M Hill; PEER; ERC, Inc; and IT Corporation)-RI activities for WAGs 1, 5, 6, and 10. Conduct assessments on inactive tanks required by FFA.

CDM Foderal Programe-Preparation of a regulatory review and sampling and analysis plan for the WAG 6 performance monitoring activity.

CER-Assistance in preparing the WAG 6 well plugging and abandonment plan.

Dr. David Daniel-Assistance in evaluating suitability of soil for caps.

EBASCO-Remedial design activities.

BCOTECH-Assistance in the analysis of surface water.

Environmental Conalting Engincern-Preparation of remediation and postremediation monitoring plans for WAG 6 and monitoring in WAG 2.

ERC, Bdgo-Geotechnical tests.

ETE Consulting Engincen-Survey services.

Gootek Drilling-Drilling services.

Gilbert Commonwealth-Preparation assistance for cost account plans and project documentation such as project management plans, health and safety plans, waste management plans, current year work plans, and configuration control support.

Highland Drilling Company-Construction and well plugging and abandonment.

H\&R Technical Asociates, Inc-Technical and administrative support such as assembling reports, preparing minutes of meetings, and reviewing reports.

Hydrocomp-Expert review of field monitoring and modeling of contaminated sediment transport in WOC.

Jecobs Engincering-Preparation of integrated RCRA/CERCLA/NEPA decision documents, including FSs, Proposed Plans, RODs, Environmental Assessments, Environmental Impact Statements, documents for interim actions, and cost estimates associated with these documents. Provision of technical support for RIs, assessments and investigations for off-site locations, remedial action verification, DOE and Energy Systems community 
relations activities, requirements associated with the Administrative Record, and risk assessments.

JAYCOR-Sampling and analysis support for benthic macroinvertebrate samples from White Oak Creek and tributaries.

Knaville Collego-Data base support and technical support for sample collections.

Locheod-Analytical services.

MK-Ferguson-Construction management.

Midweat Technical, Inc-Assistance in budgeting, planning, and cost tracking; to provide laboratory and field technical support.

North Carolina State University-Assistance in biological monitoring and abatement tasks.

Oak Ridge Aswociated Universitiea-Field services coordination.

OGDEN-Geotechnical services as required to support the remedial design architect-engineer and the Performance Assessment Program.

Peer Consultant-Administrative support (team member of SAIC).

Radian-Preparation of environmental assessments and CERCLA decision documents.

SAIC-Monitoring coordination, performance assessment and hydrologic modeling activity for the WAG 6 Performance Assessment Program.

Southweat Research-Outside laboratory services.

Temp Systems-Assistance with administrative functions and surface water monitoring.

Tennesee Valley Authority Interagency Agreement-Technical supervision of FY 1992 drilling activities, including drilling three crreholes and instrumenting them with multiport measuring systems (Westbay systems) and selecting monitoring intervals using core data, geophysical logs, and flowmeter data via the agreement.

TMA Eberlino-Outside laboratory analytical services.

University of California-Assistance in biological monitoring and abatement.

University of California Davi-Histopathological analyses of fish tissues.

University of Tennesceo-Assistance in performing data collection; data compilation; development of performance criteria, maintenance programs, and quality assurance plans; and oversight of surface-water monitoring station upgrade activities.

U.S. Geological Servico-Assistance in surface water monitoring.

Vista Research, Inc-LLLW tank system leak testing methudology development.

\section{OAK RIDGE K-25 SITE}

Adams Craft Hertz Walker-Site survey (Pond Waste Management Project).

Advanced Sciences, Inc-Data validation.

Analysas Corporation-Records management (Pond Waste Managment Project). 
Battelle, Columbus Leboratorica-Preparation of a simplified EA (Pond Waste Management Project).

Broo's Rand Laboratory-Mercury speciation analyses.

CDM Foderal Proyram:-PASI and RCRA Facility Investigation work plan preparation.

Cremred Tenneasee Corporation-Ultrasonic Ranging and Data System support.

CompuChem Laboratoric-Chemical/radiological analyses.

COR, Inc-Inventory Management Information System prototype development support (Pond Waste Management Project).

Dennis Weiter Asoca-Study of available filter press operations (Pond Waste Management Project).

Enterpriec Advioury Services, Inc-Management systems support.

BSE Biosciences Group-Bioremediation of a former underground storage tank site.

ETE Consulting Engincen-Surveying.

Geraghty and Miller-Technical support [K-25 Site Groundwater Protection Program (GWPP)].

GH Cofer-Professional services.

Gilbert Commonwealth-Estimating support.

Highland Drilling-Characterization well drilling; drilling services for K-25 Site GWPP.

HSW Environmental Consultants, Inc-Technical support (K-25 Site GWPP).

IT Corporation-Analytical support.

Jecobs Engincering-Preparation of integrated RCRA/CERCLANEPA decision documents, including FSs, Proposed Plans, RODs, Environmental Assessments, Environmental Impact Statements, documents for interim actions, and cost estimates associated with these documents. Provision of technical support for RIs, assessments and investigations for off-site locations, remedial action verification, DOE and Energy Systems community relations activities, requirements associated with the Administrative Record, and risk assessments.

Labat-Anderson-Assistance for Radian Corporation with environmental assessment for K-1407 B\&C Ponds.

Lockwood Greeno-On-site project engineering support and Title II design (Pond Waste Management Project).

A. L Lott-Operational Readiness Review Board; independent member (Pond Waste Management Project).

PAI-Technical consulting; generation of a project management plan and operational oversight management plan (Pond Waste Management Project).

SAIC-Professional services; RI subcontractor for K-770 and K-1070 OUs.

Singleton Laboratorien-Soil, geochemical, and geophysical analyses.

Tenera-Technical consulting; conduct of operations (Pond Waste Management Project). 
Univernity of Tennewee, Industrial Engineering Department-Assistance in planning for storage layout and warehousing (Pond Waste Management Project).

\subsection{ORAU AND EFPC}

Aloeon Corporation-Quantitative uncertainty analysis.

Brooks Rand Laboratoriea-Analytical support.

CompuChem Laboratorie-Analytical laboratory services.

EBASCO-Baseline support for ORAU.

ETE Consulting Engineers-Surveying.

GEOTEK-Field investigation support.

Jecobs Engincering-Preparation of integrated RCRA/CERCLA/NEPA decision documents, including FSs, Proposed Plans, RODs, Environmental Assessments, Environmental Impact Statements, documents for interim actions, and cost estimates associated with these documents. Provision of technical support for RIs, assessments and investigations for off-site locations; remedial action verification, DOE and Energy Systems community relations activities, requirements associated with the Administrative Record, and risk assessments.

Labat-Andenon-NEPA support, FS support, Administrative Record support.

MK-Fergueon-Baseline planning support for ORAU.

SAIC-EFPC RI/FS, data management, quality assurance, community relations, NEPA support.

Singleton Laboratoriea-Geotechnical laboratory services.

University of Tennesseo-Technical support of bioremediation and consulting.

\subsection{CLINCH RIVER-WATTS BAR RESERVOIR}

Advanced Sciencee, Inc. (ASI)-Laboratory and field support.

Analytical Projects Office (APO) at Martin Marietta Energy Systems, Oak Ridgo-Processing of all contracts for analyses of samples collected. The APO determines which labs will perform the analyses.

Army Corps of Engineer-Hydro-acoustic studies of the Clinch River arm of the Watts Bar Reservoir to determine the distribution, thickness, and type of bottom sediments.

Atlan-tech, Inc-Procedure writing support for the low-level radiological laboratory being used to analyze Phase 2 samples.

Automated Sciences Group-Support for various tasks in the management, collection, analysis, and interpretation of biota, water, and sediment samples; also program management assistance.

Battelle Pacific Northweat Laboratory-Technical support with water, sediment, contaminant modeling tasks. 
CDM Foderal Program-Regulatory compliance support on the White Oak Creek Embayment time-critical CERCLA removal action. [Closed]

Gilbert Commonwealth-Assistance, through a subcontract with Central Engineering, in the publishing of the first Lifecycle Baseline document. [Closed]

Jecobs Enyincering-Preparation of integrated RCRAVCERCLANEPA decision documents, including FSs, Proposed Plans, RODs, Environmental Assessments, Environmental Impact Statements, documents for interim actions, and cost estimates associated with these documents. Provision of technical support for $\mathrm{RIs}$, assessments and investigations for off-site locations, remedial action verification, DOE and Energy Systems community relations activities, requirements associated with the Administrative Record, and risk assessments.

JAYCOR-Support of data management activities and document maintenance in the production of risk assessment documents.

Michigan State University-Breeding and raising of mink in conjunction with the Clinch River ER Program's study of reproductive effects of ingesting fish from the Clinch River-Watts Bar Reservoir System.

Midweat Technical, Inc-Support of data management activities and document maintenance in the production of risk assessment documents. [Closed]

Oak Ridge Institute of Science and Energy-Support for risk assessments and contaminant transport modeling.

ORACLE-Support in the design and implementation of ORACLE-based databases and applications.

ORAU-Radioanalytical support for Phase I of the RI. [Closed]

PEER Consultant-Computer programming and bar coding support.

SAIC-Technical support and assistance in compilation of data packages, validation and verification of data packages, and analytical services coordination.

SENES, Oak Ridgo-Support for human health risk assessments.

Stidaway Institute of Oceanography, University of Georgia-Analysis of speciation of arsenic. [Closed]

Southern Illinois University-Assistance in biological data collection and sample design.

Tenneasee Valley Authority-Support for the sedimentation range cross-sections [Closed]; aerial photography and topographic mapping of White Oak Creek Embayment [Closed]; numerical modeling of water, sediment, and contaminant transport in Clinch River-Watts Bar Reservoir; sampling and analysis of water and sediment from potential sources of contaminants; review of Tennessee Valley Authority sediment-disturbing activities; sampling and contaminant analysis of key fish species in the Tennessee River System; sediment and water toxicity studies; and benthic macroinvertebrate community study at monitoring stations within the Clinch River and Poplar Creek.

University of California-Davi-_uantitative histopathological analysis of target organs of fish.

University of Tenneseco-Assistance in data collection; data compilation; data base development and management; development of procedures and maintenance/coordination of training; coordination of the Clinch River/WAG 2 document management center with 
the other Energy Systems document management centers in Oak Ridge; study of pollutant material transport, distribution, and characterization; and program management.

\subsection{ENERGY SYSTEMS ER CENTRAL DIVISTON}

Analyze-Technical integration support and DOE Model Conference support. [Closed]

Authorization Syateme, Inc-Subcontract with Wye Technologies for support of the Intelligent Document Control System for the FFA. [Closed]

Automated Compliance Systems, Inc-Analysis of sample management and data handling. [Clowed]

CDM Foderal Programe-Regulatory compliance support and waste analysis support on the Portsmouth project.

Dr. Stanley N. Davis-Groundwater consulting at Paducah. [Closed]

Ecotect Laboratory Services, Inc-Laboratory sample analysis.

Elotek Laboratory Services, Inc.-Radiologicai/analytical data analysis.

ERC, Inc-Support for a feasibility study.

H\&R Technical Aseociates, Inc-Consultation on cost/schedule control systems and groundwater data base management.

Lietze Soil Servicen-Soil consulting services.

Lockheed Analytical Services-Chemical/analytical data analysis.

Loctheed Engincering and Sciences Company-Laboratory sample analysis.

Maxima Corporation-Project management.

Micro-Frame Technologies-Off-site training and professional training support.

ORAU-5-year plan review. [Closed]

Penn Accord-Facilitation training. [Closed]

SAIC-Site-specific plan support for the development of the Oak Ridge Environmental Information System; training support; activity data sheet support; cost/schedule control system training; scheduling and technical support; waste management treatment, storage, and disposal analissis; analytical needs assessment; support services for preparation of the 5-year plan; and data management support.

S. M. Stoller Corporation-Video preparation. [Closed]

Univerzity of Tennesseo-Soil characterization, hydrogeology, and data base management support.

University of Waterloo (Canada)-Groundwater modeling.

Dr. William B. Whito-Consulting for karst hydrogeology on the ORR. [Closed] 


\subsection{JACOBS ENGINEERING}

Geraghty \& Miller-Environmental science support for the production of integrated decision documents.

Lockwood Greeno-Engineering support for the production of integrated decision documents.

PAI Corporation-Support for the production of integrated decision documents.

The Univervity of Tennemeo-Training and other support for the production of integrated decision documents.

United Science Induetrien-Support for the production of integrated decision documents. 

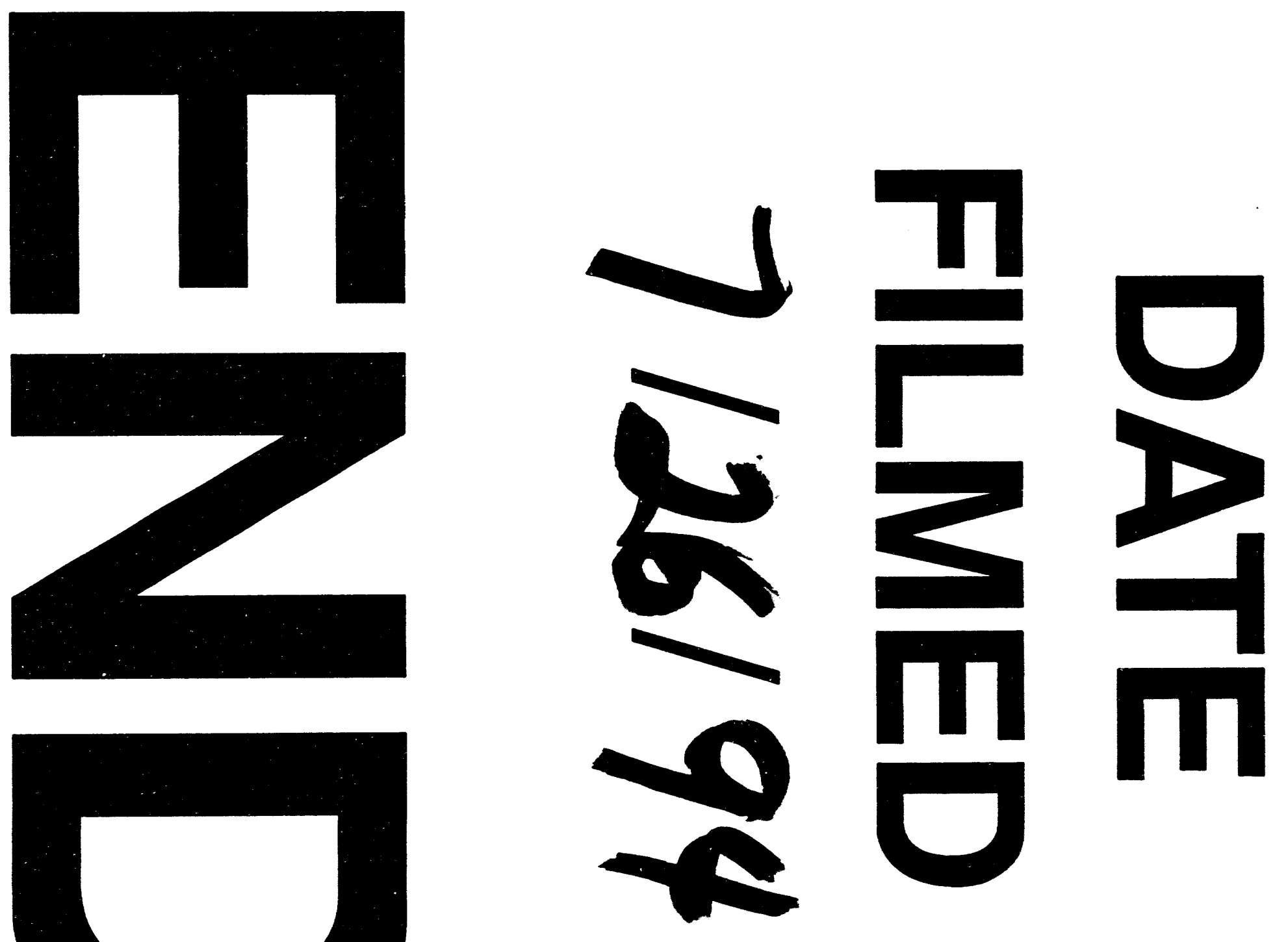
